\title{
OPTIMASI PENGOLAHAN KALDU AYAM DAN BROKOLI DALAM BENTUK INSTAN DAN ANALISA BIAYA PRODUKSI
}

\author{
Oleh: MUH. ANIAR HARI SWASONO
}

Penelitian bertujuan untuk menentukan jenis dan proporsi dan jenis tepung pada pembuatan kaldu ayam dalam bentuk instan dan mengetahui proporsi penambahan brokoli yang optimal pada pembuatan kaldu ayam instan untuk meningkatkan kualitas kaldu.Penelitian melalui dua tahap yaitu tahap I pembuatan kaldu instan dengan variable jenis dan berat tepung, penelitian tahap II pembuatan kaldu instan brokoli dengan variable pemberian brokoli dengan berat yang berbeda. Hasil penelitian menunjukkan bahwa Kombinasi perlakuan dengan tepung terigu dan berat 100 gram merupakan perlakuan terbaik tahap I yang memiliki karakteristik sebagai berikut: kadar air 5,93\%; kadar protein $11,22 \%$; kadar lemak 7,24\% dan warna kekuningan (b*) 2,31. Pada tahap II, perlakuan penambahan berat brokoli $250 \mathrm{~g}$, merupakan perlakuan terbaik yang memiliki karakteristik sebagai berikut: kadar air 5,93\%; kadar antioksidan 42,70\%; kadar protein $16,60 \%$, kadar lemak $5,43 \%$ dan kadar serat kasar 2,15\%. Berdasarkan hasil perhitungan analisa biaya produksi diperoleh Payback Periods yaitu : 2 tahun 4 bulan 16 hari. Hasil perhitungan Payback Periods lebih pendek daripada umur ekonomis proyek (5 tahun), sehingga usulan investasi ini layak untuk dilakukan. Hasil perhitungan Net Present Value (NPV) memberikan nilai sebesar Rp. 260.176.721,56. Nilai ini menunjukkan selisih nilai sekarang dari manfaat dan biaya setiap tahunnya. Nilai NPV yang lebih besar dari nol ini juga memberikan arti bahwa unit pengolahan ini layak untuk direalisasikan. Nilai PI hasil perhitungan adalah sebesar 1,91.

Kata Kunci : Optimasi, kaldu Ayam dan Brokoli, Instan, Analisa Biaya. 


\section{PENDAHULUAN}

\subsection{Latar Belakang}

Kaldu ayam merupakan salah satu bentuk produk olahan daging ayam yang sering dijumpai masyarakat. Kaldu adalah sari tulang, daging, atau sayuran yang direbus untuk mendapatkan sari bahan tersebut, mempunyai aroma dan citarasa khas, berbentuk cairan, berwarna agak kekuningan.

Kaldu sebagai produk olahan sangat jarang atau bahkan tidak dikonsumsi secara langsung, tetapi umumnya dijadikan bahan penyerta atau pemberi rasa pada masakan tertentu. Citarasa yang khas ditimbulkan terutama berkaitan dengan senyawa-senyawa protein dengan degradasi unsur-unsur gizi lainnya (lemak dan karbohidrat) yang terdapat pada bahan makanan (Anonymous, 2007ª).

Penelitian tentang kaldu sampai saat ini masih jarang dilakukan dan dipublikasikan, oleh karena itu kesulitan yang dihadapi adalah kurangnya pustaka dan acuan tentang peran dan kandungan kaldu serta dampaknya terhadap penambahan bahan penunjang lainnya.

Selain memperhatikan kepraktisan dan efisiensi, mutu dan kandungan gizi sangatlah penting diperhatikan para konsumen yang mempunyai tingkat aktivitas tinggi, oleh karena itu kaldu perlu penambahan bahan lain untuk meningkatkan kandungan nutrisi terutama serat alami yang banyak dibutuhkan untuk membantu metabolisme pencernaan.

Serat kasar merupakan komponen sayuran daun yang berkhasiat membantu metabolisme pencernaan. Karena tidak terurai oleh sistem pencernaan kita, serat kasar menjadi seperti karet busa di dalam usus dan akan menyerap zat buangan dan membantu gerakan peristaltik usus sehingga mendorong sisa makanan ke luar tubuh (Apriadji, 2001).

Salah satu tanaman yang mempunyai serat alami cukup tinggi adalah brokoli, dimana brokoli (Brassica oleracea var.italica) adalah sayuran tanaman sejenis kubis-kubisan yang merupakan kumpulan dari kuntum bunga membentuk gerombolan berupa kuntum (Sutomo, 2006). Kandungan dari brokoli sangat penting bagi tubuh kita antara lain vitamin $\mathrm{C}, \mathrm{E}$, beta karoten, serat alami dan sulforafan (Inayah, 2003).

$$
\text { Brokoli mengandung }
$$

vitamin $\mathrm{C}$ lebih banyak daripada kebanyakan jeruk, lebih banyak kalsium daripada segelas susu, lebih banyak serat dibandingkan roti gandum dan mengandung banyak antioksidan (Anonymous, $2007^{\mathrm{C}}$ ). Dengan adanya penambahan brokoli pada pembuatan kaldu ayam diharapkan produk yang dihasilkan akan meningkatkan komposisi nutrisinya terutama serat alaminya. Dewasa ini banyak industri makanan membuat produk kaldu 
dalam bentuk instan. Penggunaan kaldu semakin praktis karena tidak perlu merebus daging bersama rempah selama berjam-jam untuk menghasilkan sepanci kaldu cukup dengan menambahkan kaldu bubuk/instan ke dalam air mendidih sehingga tercipta kuah kaldu yang siap saji. Di pasaran banyak sekali dijual kaldu siap pakai, baik itu yang berbentuk bubuk, blok, ataupun cair dalam kemasan kaleng/karton. Kaldu siap olah yang beredar dipasaran saat ini dirasa kurang mengandung serat alami hal ini dapat dilihat dari komposisi bahan dan kandungan nutrisinya yang hanya menonjolkan bahan penguat rasa (MSG dan garam) yang potensial menyebabkan hipertensi karena tingginya kandungan garam dan lemak jenuh serta kolesterol (Mahbubatul, 2008). Pembuatan produk kaldu instan sangat dipengaruhi oleh adanya pengental atau bahan pembantu yang berfungsi mengikat kandungan kaldu dalam bahan sehingga tetap tersedia setelah dilakukan pemanasan. Macam bahan pengental misalnya dekstrin, tween 80, tepung dan lain-lain.

Tepung adalah partikel padat yang berbentuk butiran halus atau sangat halus tergantung pemakaiannya. Biasanya digunakan untuk keperluan penelitian, rumah tangga, dan bahan baku industri (Anonymous, $2008^{\mathrm{a}}$ ). Dengan memperhatikan aspek pengolahan dan penambahan bahan pengental serta proporsi tepung dan brokoli, diharapkan produk kaldu ayam dan brokoli instan bisa mengurangi dampak penyakit tersebut.

Permasalahan yang timbul

adalah bagaimana caranya pengolahanan kaldu ayam dalam bentuk instan yang secara kualitas dan finansialnya layak untuk diproduksi serta berapakah proporsi bahan pengental dan brokoli yang optimal pada pembuatan campuran kaldu ayam dan brokoli instan.

\subsection{Tujuan Penelitian}

Tujuan dari penelitian ini adalah :

a. Menentukan jenis dan proporsi tepung pada pembuatan kaldu ayam dalam bentuk instan .

b. Mengetahui proporsi penambahan brokoli yang optimal pada pembuatan kaldu ayam dan brokoli instan yang secara kualitas dan finansial layak.

\subsection{Manfaat Penelitian}

Diharapkan dengan adanya penelitian ini dapat menjadi acuan untuk mengetahui jenis dan proporsi tepung pada proses pembuatan kaldu ayam instan serta menyajikan data empiris tentang proporsi penambahan brokoli yang secara kualitas lebih baik.

Data yang diperoleh dapat digunakan untuk memperbaiki dan 
menentukan produksi pada pembuatan kaldu ayam dan brokoli dalam bentuk instan secara komersial melalui kajian analisa biaya produksi dan finansialnya.

\subsection{Permasalahan}

1. Bagaimana mengolah kaldu ayam instan dengan jenis dan proporsi tepung sebagai pengental yang secara kualitas baik kimia maupun sensoris layak.

2. Bagaimana cara pengolahanan kaldu ayam dan brokoli dalam bentuk instan yang secara kualitas dan finansialnya layak untuk diproduksi.

\subsection{Hipotesis}

1. Diduga dengan
penambahan tepung
terigu pada pembuatan
kaldu instan secara
kualitas baik kimia
maupun sensoris layak

2. Diduga dengan penambahan proporsi brokoli pada pembuatan campuran kaldu ayam dan brokoli dalam bentuk instan secara kualitas baik fisik maupun kimia meningkat dan layak untuk diproduksi.

\section{TINJAUAN PUSTAKA}

\subsection{Kaldu Ayam}

Kaldu adalah produk yang diperoleh dari daging atau daging unggas dengan cara memasak bahan sarinya atau hidrolisatnya dengan air, dengan atau tanpa penambahan bumbu atau bahan penyedap, lemak yang dapat dimakan, natrium klorida, rempah-rempah dan sari-sari alami atau destilatnya dan bahan makanan lain untuk meningkatkan rasa dengan tambahan bahan lain yang diizinkan dan sesuai dengan petunjuk penggunaan (Anonymous, 2003 ${ }^{\mathrm{a}}$ ).

Dalam membuat aneka masakan berkuah, khususnya sup, kaldu merupakan kunci kelezatannya. Di pasaran banyak sekali dijual kaldu siap pakai, baik itu yang berbentuk bubuk, blok, ataupun cair dalam kemasan kaleng/karton. Untuk mendapatkan cita rasa sup yang menonjol, sebaiknya memang disesuaikan antara bahan kaldu dengan jenis sup yang ingin dibuat. Misalnya saja, untuk membuat sup ayam kaldunya juga dibuat dari hasil rebusan ayam. Demikian juga dengan sup seafood, memakai kaldu dari udang/ikan, dan seterusnya (Anonymous, 2007 ). Kuah bakso seharusnya merupakan kaldu daging yang diberi bumbu sehingga menjadi kuah yang lezat untuk menyantap bakso. Kebanyakan pedagang bakso membuat kuah dari kaldu yang sangat encer karena sangat sedikit menggunakan daging. Kuah bakso biasanya ditambah MSG dalam 
jumlah tinggi (sampai 20 gram per liter kuah) (Anonymous, 2005 ${ }^{\mathrm{b}}$ ). Padahal, untuk membuat kuah bakso yang enak, tak harus menggunakan MSG tetapi dengan cara membuat kuah bakso dari bahan daging yang cukup banyak. Jumlah daging yang digunakan, sekitar 10 persen dari kuah yang dihasilkan (Anonymous, $2005^{\mathrm{b}}$ ).

Bahan dasar dari kaldu instan adalah daging sapi, daging ayam, atau seafood yang diproses layaknya membuat kaldu murni dan kemudian dikeringkan melalui proses drum drying atau spray drying hingga berbentuk bubuk. Sebelum dikemas, kaldu bubuk ini diberi tambahan pati dan zat antikempal agar kaldu tidak menggumpal (Anonymous, 2007 ${ }^{\mathrm{c}}$.

Terdapat berbagai jenis kaldu, tergantung bahan utama yang dipakai dan metode pengolahannya. Berdasarkan bahan utama yang dipergunakan, dikenal dengan kaldu sapi (beef stock), kaldu ayam (chicken stock), kaldu ikan (fish stock dan fish fummet), kaldu domba (lamb stock), dan kaldu sayuran (vegetables stock). Pada pembuatan kaldu ikan, sebagai pengganti air biasanya digunakan kaldu sayuran. Kaldu ini dapat dijernihkan lagi dengan menggunakan putih telur sehingga kotoran akan menempel, kemudian disaring. Proses ini disebut sebagai penjernihan (klarifikasi) (Anonymous, 2007 ${ }^{\mathrm{b}}$ ). Untuk membuat kaldu yang baik, pembuatannya memakan waktu yang lama, paling tidak $4-6$ jam untuk kaldu sapi, 2 - 3 jam untuk kaldu ayam dan sekitar satu jam untuk kaldu ikan dan sayuran (Anonymous, $2003^{\mathrm{a}}$ ).

Departemen Perindustrian telah mengeluarkan standar mutu kaldu daging yaitu Standar Nasional Indonesia (SNI) No. 01-4218-1996. Standar ini meliputi beberapa parameter penting yang mempengaruhi kualitas kaldu daging tersebut. Adapun persyaratan mutu kaldu dapat dilihat pada Tabel 1 .

Tabel 1. Persyaratan Mutu Kaldu

\begin{tabular}{|l|l|}
\hline \multicolumn{1}{|c|}{ Parameter } & \multicolumn{1}{c|}{ Keterangan (\%) } \\
\hline Warna, bau dan rasa & Normal \\
Kadar nitrogen total & Min. 0,01 (kaldu daging, kaldu unggas) \\
& Min. 0,04 (kaldu daging lainnya) \\
Kadar nitrogen amino & Min. 0,02 (kaldu daging lainnya) \\
Nitrogen klorida & Maks. 1,25 \\
Lemak & Min. 0,3 (kaldu daging berlemak) \\
\hline
\end{tabular}

Sumber: Anonymous (2003 $)$

\section{Astawan dalam Anonymous $\left(2007^{\mathrm{d}}\right)$ menyatakan bahwa, pemilihan jenis makanan tak lagi}

hanya didasarkan pada kandungan gizi serta kelezatannya. Konsumen menginginkan makanan yang tidak 
hanya membuat tubuh sehat, tetapi

juga mampu mengusir efek negatif

dari penyakit. Para peneliti membuktikan bahwa sup ayam mempunyai kandungan zat- zat anti paradangan yang mampu meredakan peradangan yang menyertai flu. zatzat tersebut ternyata mampu menghentikan gerakan neutrofil, salah satu jenis sel darah putih yang berperan dalan aliran cairan lendir (mukus), yang berkumpul dihidung dan paru paru. Daging ayam mempunyai kandungan protein yang tinggi sehingga dapat berperan dalam membantu masa pemulihan (table 2 dan table 3 ), selain itu sup ayam mengandung sayuran yang sangat baik dan bermanfaat bagi tubuh (Kanoni, 1997). Penambahan brokoli pada pembuatan kaldu ditujukan untuk memenuhi kebutuhan konsumen yang peduli tentang kesehatannya karena kandungan brokoli bisa mengurangi penyakit kanker. 
Table 2. Kandungan zat- zat dalam berbagai komoditi daging (\%)

\begin{tabular}{|c|l|c|c|c|}
\hline No. & \multicolumn{1}{|c|}{ Komoditi } & Kalori & Protein & Lemak \\
\hline 1 & Daging sapi & 207 & 18.8 & 14 \\
\hline 2 & Daging kerbau & 85 & 18.7 & 0.5 \\
\hline 3 & Daging kambing & 154 & 16.6 & 9.2 \\
\hline 4 & Daging domba & 206 & 17.1 & 14.8 \\
\hline 5 & Daging ayam & 302 & 18.2 & 25.0 \\
\hline 6 & Daging itik & 326 & 16.0 & 28.6 \\
\hline
\end{tabular}

Sumber : Karyadi dan Muhilal dalam Kanoni, (1997)

Tabel 3. Nilai gizi Telur, Daging Ayam dan Susu

\begin{tabular}{|c|l|c|c|c|}
\hline No. & \multicolumn{1}{|c|}{ Zat Gizi/100 gr } & Telur & Daging Ayam & Susu \\
\hline 1 & Kalori (kkal) & 173 & 404 & 6.1 \\
\hline 2 & Protein (gr) & 13 & 18.2 & 3.2 \\
\hline 3 & Lemak (gr) & 13 & 25 & 3.5 \\
\hline 4 & Hidrat arang (gr) & 0.1 & - & 4.3 \\
\hline 5 & Kolesterol (gr) & 550 & 60 & - \\
\hline 6 & Vitamin A (mcg) & 660 & 243 & 130 \\
\hline 7 & Vitamin D (mcg) & 1.3 & - & - \\
\hline 8 & Vitamin E (mcg) & 2.1 & - & - \\
\hline 9 & Vitamin B (mcg) & 0.4 & 0.8 & 0.03 \\
\hline 10 & Vitamin B12 (mcg) & 1.8 & - & - \\
\hline 11 & Riboflavin (mg) & 0.3 & 0.16 & - \\
\hline 12 & Asam Nicotenat (mg) & 0.1 & 0.12 & 1 \\
\hline 13 & Cholin (mg) & 504 & - & - \\
\hline 14 & Pyrodorin (mg) & 0.25 & - & - \\
\hline 15 & Asam Folat (mg) & 70 & - & - \\
\hline 16 & Inositol (mcg) & 33 & - & - \\
\hline 17 & Biotin (mcg) & 22.8 & - & - \\
\hline & MINERAL & & & \\
\hline 18 & Ca (mg & 60 & 14 & 143 \\
\hline
\end{tabular}




\begin{tabular}{|c|l|c|c|c|}
\hline 19 & $\mathrm{P}(\mathrm{mg})$ & 240 & 200 & 60 \\
\hline 20 & $\mathrm{Fe}(\mathrm{mg})$ & 2.2 & 1.5 & 1.7 \\
\hline 21 & $\mathrm{Mg}(\mathrm{mg})$ & 12 & - & - \\
\hline 22 & $\mathrm{~K}(\mathrm{mg})$ & 149 & - & - \\
\hline 23 & $\mathrm{Na} \mathrm{(mg)}$ & 177 & - & - \\
\hline 24 & $\mathrm{Zn}(\mathrm{mg})$ & 1.3 & - & - \\
\hline
\end{tabular}

Sumber : Anggorodi dalam Kanoni, (1997)

\subsection{Tepung}

Tepung adalah partikel padat yang berbentuk butiran halus atau sangat halus tergantung pemakaiannya. Biasanya digunakan untuk keperluan penelitian, rumah tangga, dan bahan baku industri. Dilihat dari bahan dasarnya tepung terdiri dari tepung nabati dan tepung hewani. Tepung nabati misalnya tepung terigu dari gandum, tapioka dari singkong dan tepung maizena dari jagung sedangkan tepung hewani misalnya tepung tulang dan tepung ikan (Anonymous, 2008 ${ }^{\mathrm{a}}$ ).

Terigu adalah tepung atau bubuk halus yang bersal dari biji gandum dan digunakan sebagai bahan dasar membuat kue, mie adan roti. Kata terigu dalam bahasa Indonesia diserap dari bahasa portugis trigo yang berarti gandum. Tepung terigu banyak mengandung zat pati yaitu karbohidrat komplek yang tidak larut dalam air. Tepung terigu juga mengandung protein dalam bentuk gluten, yang berperan dalam menentukan kekenyalan makanan (Anonymous, 2008 ).

Tepung tapioka (Tapioca starch) biasanya disebut aci atau tepung kanji yang dibuat dari saripati ketela pohon. Biasanya dipakai untuk membuat panganan tradisional, selain itu juga digunakan sebagai pengental makanan karena warnanya yang bening, kental dan bersifat agak lengket (sticky) bila dipanaskan (Anonymous, 2000).

Tepung maizena (Maizena starch) merupakan tepung yang berwarna putih yang terbuat dari saripati biji jagung. Tepung maizena biasanya digunakan untuk mengentalkan sup atau membuat cookies atau membuat makanan lain menjadi lebih lembut (Anonymous, $2008^{\mathrm{b}}$ ).

\subsection{Brokoli}

Sayuran daun hijau kaya akan senyawa karotenoid, yang terbungkus dalam kantung pigmen hijau daun (klorofil). Makin pekat warna sayuran, makin tinggi kandungan karotenoidnya. Di dalam tubuh, karotenoid ini akan mengaktifkan enzim fase-2, yang berfungsi membersihkan sampah kimia pemicu kanker. Kemujaraban sayuran hijau memang telah diakui banyak peneliti (Hartono, 1999). Hal ini dikarenakan kandungan karotenoidnya bukan karotenoid tunggal, Namun merupakan kumpulan dari beberapa karotenoid 
aktif, khususnya betakaroten, alfakaroten, dan lutein. Tak heran jika kekuatannya menghabisi sel kanker menjadi berlipat ganda . Salah satu sayuran itu adalah brokoli. Brokoli (Brassica oleracea var.italica) adalah Bunga dari sayuran tanaman sejenis kubiskubisan. Sayuran ini merupakan kumpulan dari kuntum bunga yang membentuk gerombolan berupa kuntum (Sutomo, 2006).

Brokoli merupakan tanaman sayuran dari suku brassicaeae yang berasal dari daerah laut tengah dan sudah sejak masa Yunani Kuno dibudidayakan. Brokoli masuk ke Indonesia baru tahun 1970-an hingga sekarang cukup populer sebagai bahan pangan (Anonymous, 2008 ${ }^{\mathrm{c}}$ ). Bagian brokoli yang dapat dimakan adalah kepala bunga berwarna hijau yang tersusun rapat seperti cabang pohon dengan batang tebal. Sebagai makanan, biasanya dapat disajikan dengan direbus, dikukus, sebagai bahan tambahan sup atau dapat pula dimakan mentah karena brokoli mengandung vitamin $\mathrm{C}$ dan serat makanan dalam jumlah banyak (Anonymous, 2008 ${ }^{\mathrm{c}}$ ).
Brokoli dan sayur-sayuran dari famili Cruciferae lainnya, seperti kembang kol (cauliflower) dan kol (cabbage), bersifat antikanker. Khasiat antikanker ini dikaitkan dengan kandungan senyawa glukosinolat yang tinggi. Enzim myrosinase yang terdapat dalam sel sayur-sayuran akan menghidrolisis glukosinolat menjadi berbagai senyawa (Wirakusumah, 2005)

Brokoli merupakan salah satu sayuran dengan kandungan gizi terpadat. Satu cangkir brokoli sama dengan jumlah protein satu cangkir jagung/nasi, tapi kalorinya hanya $1 / 3$ nya. Brokoli juga disebut sayur ajaib karena mengandung sumber antikanker dan antioksidan yang tinggi protein. Kandungan seratnya $1 / 2$ roti gandum, tetapi kalorinya hanya $1 / 10$. Jenis kubis-kubisan jika dimakan bersama makanan sumber protein, karena tersebut membantu memperlancar aliran asam amino dalam darah menuju otak (Anonymous, 2004). Kandungan gizi brokoli dapat dilihat pada Tabel 4.

Tabel 4. Kandungan gizi brokoli dalam 100 gr BDD

\begin{tabular}{|l|c|}
\hline Kandungan gizi & Jumlah \\
\hline Energi & $22.0 \mathrm{kal}$ \\
Protein & $2.10 \mathrm{~g}$ \\
Lemak & $0.10 \mathrm{~g}$ \\
Karbohidrat & $4.50 \mathrm{~g}$ \\
Kalsium & $52.00 \mathrm{mg}$ \\
Fosfor & $54.00 \mathrm{mg}$ \\
\hline
\end{tabular}




\begin{tabular}{|l|c|}
\hline Serat & $0.50 \mathrm{~g}$ \\
Besi & $0.80 \mathrm{mg}$ \\
Vitamin A & $210.00 \mathrm{RE}$ \\
Vitamin B1 & $0.09 \mathrm{mg}$ \\
Vitamin B2 & $0.08 \mathrm{mg}$ \\
Vitamin C & $68.00 \mathrm{mg}$ \\
Niacin & $0.50 \mathrm{mg}$ \\
\hline
\end{tabular}

Sumber : Wirakusumah (2005)

Sebagai sayuran antikanker, terbukti bahwa orang yang mengkonsumsi brokoli rendah kemungkinan terkena kanker esofagus, perut, usus besar, paru, laring, prostat, mulut dan faring. Rating tertinggi adalah antikanker colon, itu sebabnya wanita dianjurkan banyak mengkonsumsi brokoli, selain juga mengurangi risiko kanker rahim (Apriadji, 2001). Seperti sayuran lain, brokoli kaya akan provitamin A (karotenoid), asam folat dan vitamin C. Selain vitamin, brokoli juga mengandung beragam mineral penting seperti kalsium, potasium, kalium, besi dan selenium. Zat lain yang terkandung di dalam brokoli adalah sulfur dalam bentuk glukosinolat, senyawa antidot, monoterpene dan genestein (Inayah, 2003). Flvonoid dan serat terkandung juga memperkaya kandungan nutrisi dari brokoli. Brokoli memiliki beragam manfaat untuk kesehatan tubuh, seperti mencegah terjadinya kanker kolon, kanker prostat, kanker paru dan kanker perut. Zat terkandung di dalam brokoli juga bermanfaat sebagai antioksidan. Sedangkan seratnya bermanfaat untuk mencegah konstipasi/sembelit dan ganguan pencernaan lainnya (Sutomo, 2006)

Brokoli baik dikonsumsi secara dimasak terlebih dahulu maupun mentah. Memasak brokoli terlalu matang dapat menjadikan sulfur yang sangat kuat. Kukus brokoli selama 3-4 menit atau rebus kira-kira 1 inci di atas air mendidih dalam waktu yang kurang lebih sama dengan di atas (Inayah, 2003). Proses pemasakan brokoli tidak terlalu lama agar warnanya tetap hijau terang. Memasak brokoli terlalu matang akan membuat brokoli menjadi berwarna hijau kehitam-hitaman dan menghilangkan kadar nutrisinya, terutama vitamin C (Inayah, 2003)

\subsection{Makanan Instan}

Pangan merupakan makanan dan/atau minuman yang sudah diolah dan siap untuk disajikan di tempat usaha atau di luar tempat usaha atas dasar pesanan (PP No. 28 Tahun 2004 tentang Keamanan, Mutu dan Gizi Pangan). Di dalam berproduksi IPSS harus memenuhi aspek-aspek keamanan pangan, 
yaitu aman, bermutu dan bergizi. Untuk menghasilkan pangan yang aman, bermutu dan bergizi tersebut, IPSS harus melakukan praktikpraktik higiene dan sanitasi dalam pengolahan pangan, yaitu upaya untuk mengendalikan faktor bahan baku, proses, orang, tempat dan perlengkapannya yang dapat menimbulkan penyakit atau gangguan kesehatan (Anonymous, 2006). Untuk menghasilkan pangan yang aman dan bermutu serta mencegah terjadinya penularan penyakit pada konsumen, Industri Pangan harus berpedoman pada CPPSSB (Cara Produksi Pangan Siap Saji yang Baik).

Ketika orang modern bicara soal makanan, masalah gizi selalu menjadi perhatian. Soal ini pula yang dipertanyakan saat orang mengonsumsi makanan serba praktis, apakah lauk-pauk dalam kaleng, nugget atau juga corn flakes sebagai makanan untuk sarapan. Bumbu-bumbu instan yang ditawarkan variasinya kian hari kian bertambah. Ibaratnya tinggal tambah air atau santan, maka sudah jadi makanan yang dulu dengan susah payah disiapkan oleh orangtua jaman dahulu. Kekhawatiran lain adalah makanan yang tak segar akan menimbulkan penyakit. Kandungan gizinya bisa sama dengan makanan segar karena makanan instan diproses dengan cara tertentu sehingga kandungan gizinya tak hilang (Makawi dalam Anonymous, $2007^{c}$ )
Kaldu instan merupakan salah satu sajian makanan siap olah/. Menggunakan kaldu instan memang praktis, cukup dengan mendidihkan air dan memasukkan kaldu instan tidak sampai 10 menit, kaldu sudah tersedia. Tak heran jika banyak ibu rumah tangga yang gemar menggunakan kaldu instan ini untuk memasak. Selain itu kaldu instan memiliki keunggulan yaitu kestabilan produk dan massanya lebih kecil serta bisa memenuhi pangsa pasar untuk permintaan dalam skala besar (Susilo, 2005).

\subsection{Serat Makanan Dan} Antioksidan

Serat pangan atau dietary

fiber adalah karbohidrat

(polisakarida) dan lignin yang tidak dapat dihidrolisis (dicerna) oleh enzim pencernaan manusia, dan akan sampai di usus besar (kolon) dalam keadaan utuh. Oleh karena itu, kebanyakan serat pangan akan menjadi substrat bagi fermentasi bakteri yang hidup di kolon (Wirakusumah, 2005).

Serat pangan terbukti dapat mengurangi risiko kanker, misalnya kanker kolon, dan penyakit jantung koroner. Serat pangan berperan melalui berbagai mekanisme kerja yang meliputi pengenceran isi kolon, absorbsi asam empedu dan karsinogen lainnya, penurunan waktu penahanan feses atau bersifat laksatif ringan, dan pengubahan metabolisme asam empedu (Apriadji, 1999). 
Serat dalam makanan dapat dibedakan atas serat yang larut dan tidak larut dalam air. Serat yang tidak larut dalam air adalah selulosa, hemiselulosa, dan lignin, sedangkan serat larut yang dikenal selama ini adalah pektin, gum, musilase. Serat larut bermanfaat dalam menurunkan kadar kolesterol darah karena mempunyai kemampuan untuk mengikat lemak, kolesterol dan asam empedu. Akibatnya, asam empedu di dalam hati berkurang. Untuk memproduksi asam empedu yang hilang, hati akan menarik kolesterol dari darah sehingga kadar kolesterol darah akan menurun (Inayah, 2003).

Serat kasar merupakan komponen lain sayuran daun yang berkhasiat antikanker. Karena tidak terurai oleh sistem pencernaan kita, serat kasar menjadi seperti karet busa di dalam usus. Ia akan menyerap zat buangan dan membantu gerakan peristaltik usus mendorong sisa makanan ke luar tubuh (Apriadji, 2001). Konsumsi sayuran daun yang teratur dan mencukupi juga bermanfaat menjaga kadar normal lemak darah. Dengan adanya serat sayuran di dalam usus, asam empedu akan terserap ke dalam serat dan terbuang bersama kotoran. Menurunnya asam empedu ini merangsang tubuh menarik lemak dari dalam darah untuk diproses menjadi asam empedu di dalam hati (Apriadji, 2001). Akibatnya, konsentrasi lemak dalam darah bisa tetap terjaga. Melalui proses inilah kita terhindar dari kemungkinan memiliki kadar lemak darah melebihi normal (hiperlipidemia). Sehingga kita jauh dari aneka penyakit akibat gangguan pada pembuluh darah, seperti hipertensi, stroke, sakit jantung koroner, katarak, dan juga impotensi (Apriadji, 2001).

Selain berfungsi sebagai penambah serat, sayuran juga berfungsi sebagai zat antioksidan. Antioksidan adalah senyawa yang mempunyai struktur molekul yang dapat memberikan elektronnya dengan Cuma-Cuma kepada molekul radikal bebas tanpa terganggu sama sekali dan dapat memutus reaksi berantai dari radikal bebas (Kumalaningsih, 2006).

Beberapa ilmuan semula menggunakan istilah radikal bebas untuk suatu kelompok atom yang membentuk suatu molekul, para ilmuwan tidak percaya bahwa radikal bebas dapat berada dalam keadaan bebas. Istilah radikal bebas kemudian diartikan sebagai molekul yang relatif tidak stabil yang mempunyai satu atau lebih elektron yang tidak berpasangan di orbit luarnya (Gomberg dalam Inayah, 2003). Kumalaningsih (2006) mengatakan bahwa radikal bebas adalah atom atau senyawa yang kehilangan pasangan elektronnya. Jika radikal bebas sudah terbentuk, maka di dalam tubuh akan terjadi reaksi berantai. Hal ini pada akhirnya akan menghasilkan radikal 
bebas baru sehingga jumlahnya terus bertambah dan berantai sehingga menyerang sel-sel tubuh. Akibat serangan itu, sel-sel tubuh mengalami kerusakan, dan ini bisa menimbulkan penyakit.

\subsection{Daya Terima Panelis}

Penilaian organoleptik adalah salah satu penilaian mutu makanan yang bersifat subyektif karena melibatkan panca indera. Daya penerimaan terhadap suatu makanan sangat ditentukan oleh rangsangan yang ditimbulkan makanan melalui indera manusia. Faktor utama yang mempengaruhi daya terima adalah citarasa makanan (Winarno, 2003).

Menurut Winarno (2003), citarasa sangat menentukan daya terima masyarakat secara organoleptik yang terdiri dari:

a. Warna

Secara visual faktor warna lebih dahulu sangat menentukan. Warna juga dapat digunakan sebagai indikator kesegaran dan kematangan, baik tidaknya cara pencampuran atau cara pengolahan.

b. Aroma

Aroma adalah rangsangan yang ditangkap oleh indera penciuman. Komponen aroma bahan makanan dapat digunakan untuk membedakan antar bahan makanan yang satu dengan yang lain dan sifat ini sukar dinilai dengan alat.

c. Rasa
Rasa lebih banyak melibatkan indera lidah. Rasa dapat dibagi menjadi asam, asin, manis dan pahit.

\section{BAHAN DAN METODE PENELITIAN}

\subsection{Tempat dan Waktu}

Penelitian ini dilaksanakan pada bulan April 2008 sampai bulan Juni 2008 bertempat di Laboratorium Rekayasa Teknologi Industri Pertanian Universitas Brawijaya Malang dan Laboratorium Teknologi Hasil Pertanian Universitas Muhammadiyah Malang.

\subsection{Alat dan Bahan yang digunakan.}

Alat dan bahan yang digunakan dalam penelitian terdiri dari :

1. Alat pembuatan kaldu : Panci stainlesteel, Kompor gas, Timbangan, Pisau dan Saringan.

2. Alat Pembuat Kaldu Instan: Timbangan, Oven, Saringan, Blender.

3 Bahan pembuatan Kaldu Instan Brokoli : Potongan kepala dan kaki ayam, tepung, garam, air, bawang putih dan brokoli.

\subsection{Metode Penelitian}

Rancangan penelitian meliputi :
A. Penelitian Tahap I 
Dengan meneliti pembuatan kaldu instan. Metode penelitiannya adalah dengan Rancangan Acak Kelompok (RAK) faktorial dimana terdiri dari 2 faktor.

- Faktor pertama yaitu : Jenis Tepung (T) yang terdiri dari :

$$
\begin{array}{ll}
\text { T1 } & \text { : Tepung terigu } \\
\text { T2 } & \text { : Tepung maizena } \\
\text { T3 } & \text { : Tepung tapioka }
\end{array}
$$

- Faktor kedua yaitu berat tepung (B) yang terdiri dari :

$$
\begin{array}{ll}
\text { B1 } & : 50 \mathrm{gr} / \mathrm{lt} \\
\mathrm{B} 2 & : 100 \mathrm{gr} / \mathrm{lt} \\
\mathrm{B} 3 & : 150 \mathrm{gr} / \mathrm{lt} \\
\mathrm{B} 4 & : 200 \mathrm{gr} / \mathrm{lt}
\end{array}
$$

Masing-masing perlakuan diulang 3 kali sehingga terdapat 36 perlakuan.

\subsubsection{Pelaksanaan Penelitian :}

Pelaksanaan penelitian meliputi persiapan alat dan bahan yang digunakan. Daging ayam (kepala dan kaki) dicuci sampai bersih, potong-potong agak kecil dan dilakukan blanching (perebusan pada air mendidih) lebih kurang 3 menit. Mempersiapkan panci stainlessteel yang berisi air dan masak air sampai mendidih, lalu dimasukkan potongan daging ayam dan bawang putih kedalam panci dan dimasak dengan api kecil selama 2 jam. Setelah 2 jam daging diambil dan air kaldu disaring sehingga didapat kaldu cair yang berwarna putih agak kekuningan.

$$
\text { Untuk }
$$
proses penepungan/instan, kaldu cair yang sudah jadi diberi tambahan tepung sesuai dengan perlakuan dan ditambahkan garam halus sebanyak 50 gr/lt dan diaduk sampai rata. Setelah itu masukkan dalam loyang untuk dilakukan pengovenan selama kurang lebih 8 jam dan dilakukan penepungan. Hasil tepung kaldu ditumbuk/dihaluskan dan disaring/ayak. Kaldu instan yang sudah jadi ditimbang dan dilakukan pengamatan.

Pengamatan meliputi Kadar Air, kadar lemak (Apriyanto,1989), kadar protein dan analisa organoleptik yang meliputi analisa kesukaan terhadap warna, bau, dan rasa (Friedman, 1984).

\section{B. Penelitian Tahap II}

Penelitian tahap kedua merupakan lanjutan dari hasil penelitian tahap I, dimana hasil yang paling baik pada penelitian tahap pertama merupakan dasar penelitian tahap kedua. Pada penelitian ini menggunakan rancangan acak Tunggal, yaitu penambahan brokoli dengan proporsi brokoli (W) berbeda yang terdiri dari :

$\begin{array}{ll}\text { W1 } & : 50 \mathrm{gr} / \mathrm{lt} \\ \text { W2 } & : 100 \mathrm{gr} / \mathrm{lt} \\ \text { W3 } & : 150 \mathrm{gr} / \mathrm{lt} \\ \text { W4 } & : 200 \mathrm{gr} / \mathrm{lt} \\ \text { W5 } & : 250 \mathrm{gr} / \mathrm{lt}\end{array}$

Masing-masing perlakuan diulang sebanyak tiga kali sehingga didapat 15 perlakuan.

Pelaksanaan penelitiannya adalah sebagai berikut :

Pelaksanaan penelitian meliputi persiapan alat dan bahan yang digunakan, melakukan 
pembuatan kaldu cair sesuai dengan penelitian pertama. Mengambil brokoli, lalu ditimbang sesuai perlakuan, dan dimasukkan dalam blender serta ditambah air matang $200 \mathrm{ml}$ lalu diblender. Hasil blenderan disaring dan dimasukkan dalam kaldu cair yang masih panas dan masak selama 3-4 menit. Setelah itu disaring dan ditambah dengan tepung dan garam, dan dilakukan penepungan dengan menggunakan oven. Setelah jadi ditumbuk dan diayak lalu dilakukan pengamatan.

Pengamatan meliputi kadar lemak dan protein analisa organoleptik yang meliputi analisa kesukaan terhadap warna, bau, dan rasa (Friedman, 1984) dan kandungan antioksidan dan serat alam

$\begin{array}{lrr} & \text { Analisa Perbandingan } \\ \text { produk menggunakan } & \text { uji } \\ \text { Organoleptik dilakukan untuk }\end{array}$
mengetahui perbandingan tingkat kesukaan konsumen terhadap kaldu instan brokoli dibandingkan produk yang sudah beredar di pasar yaitu kaldu "B" rasa ayam dan kaldu "A" rasa ayam. Pengamatan meliputi warna, rasa, aroma.

\subsection{Analisa Data}

Data yang didapat dari hasil pengamatan setelah perlakuan penelitian tahap I pada masingmasing variabel dimasukkan dalam tabel untuk dianalisa Uji $\mathrm{F}$ Sidik Ragam dan jika terdapat perbedaan nyata dilanjutkan dengan Uji DMRT
(Duncan) $1 \%$, Sedangkan penelitian tahap II dianalisa dengan uji $\mathrm{F}$ dan jika terdapat perbedaan dianalisa dengan uji BNT 1\%, pemilihan perlakuan terbaik menggunakan Indeks Efektifitas.

\section{HASIL DAN PEMBAHASAN}

\subsection{Penelitian Tahap I : Pengaruh Jenis Dan Proporsi Tepung Terhadap Kualitas Kaldu Instan}

$$
\text { Pengamatan pada }
$$

penelitian Tahap I meliputi kadar air, kadar protein, kadar lemak dan warna kekuningan $\left(b^{*}\right)$.

\subsubsection{Kadar Air}

Air merupakan komponen penting dalam bahan makanan, karena air dapat mempengaruhi penampakkan, tekstur dan cita rasa dari makanan tersebut. Kadar air juga mempengaruhi daya simpan bahan pangan karena dapat mengontrol pertumbuhan mikroorganisme (Belitz and Grosch, 1999).

Rerata kadar air pada berbagai perlakuan antara jenis tepung dengan berat yang dihasilkan berkisar antara 3,96 - 7,80\% (Lampiran 2). Hasil analisis sidik ragam (Lampiran 2) menunjukkan bahwa adanya perbedaan jenis tepung dan berat serta interaksi antar perlakuan memberikan pengaruh sangat nyata $(\alpha=0,01)$ terhadap 
kadar air. Rerata nilai kadar air pada berbagai perlakuan ditunjukkan pada Tabel 6 .

Tabel 6 menunjukkan uji DMRT $(\alpha=0,01)$ perlakuan terbaik kadar air diperoleh dari terigu dengan berat $50 \mathrm{~g}$ sebesar 3,96\% dan sangat berbeda nyata dengan yang lain. Winarno (1992) menyatakan bahwa dalam bahan makanan, air merupakan komponen yang penting, karena air dapat mempengaruhi penampakan, tekstur, serta cita rasa makanan. Disamping itu kandungan air didalam bahan makanan ikut menentukan acceptability, kesegaran, dan daya tahan bahan tersebut.

\section{Tabel 6. Rerata Kadar Air (\%) pada Berbagai Perlakuan}

\begin{tabular}{|c|c|c|}
\hline Perlakuan & $\begin{array}{c}\text { Rerata } \\
\text { Kadar Air (\%) }\end{array}$ & $\begin{array}{c}\text { DMRT } \\
(\alpha=0,01)\end{array}$ \\
\hline Terigu dengan berat $50 \mathrm{~g}$ & $3,96 \mathrm{a}$ & 1,24 \\
\hline Terigu dengan berat $100 \mathrm{~g}$ & $5,93 \mathrm{ef}$ & 1,43 \\
\hline Terigu dengan berat $150 \mathrm{~g}$ & $4,40 \mathrm{ab}$ & 1,30 \\
\hline Terigu dengan berat $200 \mathrm{~g}$ & $4,71 \mathrm{abc}$ & 1,36 \\
\hline Maizena dengan berat $50 \mathrm{~g}$ & $4,94 \mathrm{bcd}$ & 1,40 \\
\hline Maizena dengan berat $100 \mathrm{~g}$ & $7,80 \mathrm{~g}$ & - \\
\hline Maizena dengan berat $150 \mathrm{~g}$ & $5,27 \mathrm{cde}$ & 1,42 \\
\hline Maizena dengan berat $200 \mathrm{~g}$ & $4,84 \mathrm{bc}$ & 1,39 \\
\hline Tapioka dengan berat $50 \mathrm{~g}$ & $6,11 \mathrm{f}$ & 1,43 \\
\hline Tapioka dengan berat $100 \mathrm{~g}$ & 5,64def & 1,43 \\
\hline Tapioka dengan berat $150 \mathrm{~g}$ & $4,67 \mathrm{abc}$ & 1,33 \\
\hline Tapioka dengan berat $200 \mathrm{~g}$ & $5,26 \mathrm{cde}$ & 1,41 \\
\hline
\end{tabular}

Keterangan: Angka rerata yang diikuti dengan huruf yang sama pada kolom yang sama tidak berbeda nyata pada uji Duncan $1 \%$ 


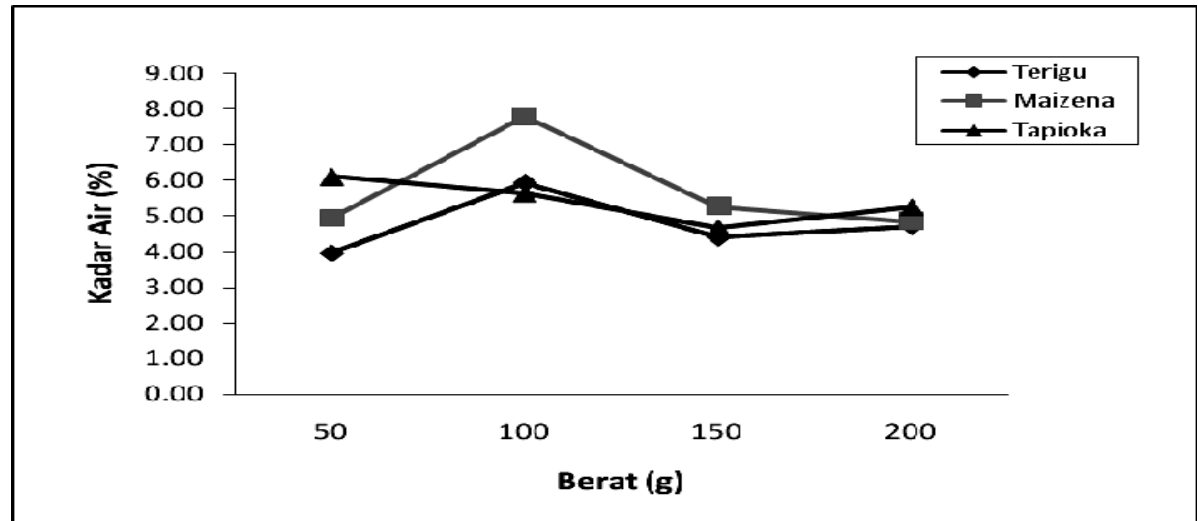

Gambar 1. Grafik rerata Kadar Air (\%) pada Berbagai Perlakuan 
Gambar 1. menunjukkan bahwa kadar air tertinggi diperoleh pada perlakuan maizena dengan berat $100 \mathrm{~g}$ sebesar $7,80 \%$ dan terendah pada terigu dengan berat 50 g sebesar 3,96\%. Dari hasil analisa menunjukkan adanya penurunan kadar air pada penambahan berat tepung, hal ini karena pada proses pengeringan air yang diserap bahan membuat lekat gumpalan-gumpalan dan air menguap dari dalam partikel sehingga menyebabkan pengerutan yang disertai dengan terbentuknya saluran, rengkah dan berpori (Kumalaningsih, 1990). Kadar air sangat penting untuk diuji karena berkaitan dengan pertumbuhan mikroorganisme. Penurunan kadar air bahan (Aw) dapat menghindarkan bahan pangan dari kerusakan pertumbuhan mikroorganisme. Selain itu kadar air berpengaruh terhadap tekstur dan jumlah kadar air menentukan kualitas proses pengemasan dan penyimpanan (Widianarko, 2006).

Penggunaan tepung dengan kandungan karbohidrat (amilum) tinggi dengan kombinasi protein dalam kaldu yang cukup tinggi pada saat pemanasan maka terjadi proses gelatinasi pati dan denaturasi protein yang mengakibatkan terbentuknya matriks antara pati dan protein. Hal ini mengakibatkan terperangkapnya air dalam matriks tersebut sehingga strukturnya berubah (Utomo, 2008).

\subsubsection{Kadar Protein}

Protein merupakan bagian yang sangat penting karena sebagian besar jaringan tubuh, protein adalah komponen terbesar setelah air. Protein juga merupakan sumber-sumber asam amino, yang mengandung unsur $\mathrm{C}, \mathrm{H}$, $\mathrm{O}$, dan $\mathrm{N}$ yang tidak dimiliki oleh lemak dan karbohidrat (Winarno, 2003). Apabila protein dihidrolisis dengan sempurna maka akan diperoleh hidrolisat yang terdiri dari campuran 18 sampai 20 jenis asam amino yang terikat dalam jumlah yang bisa mencapai ribuan, karena antar asam amino terdapat ikatan peptida yang terjadi antara atom $\mathrm{C}$ dari gugus $(-\mathrm{COOH})$ dengan atom $\mathrm{N}$ dari gugus amin $\left(\mathrm{NH}_{2}\right)$ (Lehninger, 1982)

Hasil analisis sidik ragam (Lampiran 3) menunjukkan bahwa adanya perbedaan jenis tepung dan berat serta interaksi antar perlakuan memberikan pengaruh sangat nyata $(\alpha$ $=0,01)$ terhadap kadar protein. Rerata kadar protein pada perlakuan antara jenis tepung dengan berat yang dihasilkan berkisar antara 3,49 11,22\% (Lampiran 3). Rerata nilai kadar protein pada berbagai perlakuan ditunjukkan pada Tabel 7. 
Tabel 7. Rerata Kadar Protein (\%) pada Berbagai Perlakuan

\begin{tabular}{|l|c|c|}
\hline \multicolumn{1}{|c|}{ Perlakuan } & $\begin{array}{c}\text { Rerata } \\
\text { Kadar Protein (\%) }\end{array}$ & $\begin{array}{c}\text { DMRT } \\
(\mathbf{\alpha = 0 , 0 1 )}\end{array}$ \\
\hline Terigu dengan berat $50 \mathrm{~g}$ & $10,44 \mathrm{f}$ & 1,35 \\
\hline Terigu dengan berat $100 \mathrm{~g}$ & $11,22 \mathrm{~g}$ & - \\
\hline Terigu dengan berat $150 \mathrm{~g}$ & $9,01 \mathrm{e}$ & 1,35 \\
\hline Terigu dengan berat $200 \mathrm{~g}$ & $10,93 \mathrm{fg}$ & 1,35 \\
\hline Maizena dengan berat $50 \mathrm{~g}$ & $4,91 \mathrm{c}$ & 1,33 \\
\hline Maizena dengan berat $100 \mathrm{~g}$ & $3,49 \mathrm{a}$ & 1,17 \\
\hline Maizena dengan berat $150 \mathrm{~g}$ & $4,02 \mathrm{ab}$ & 1,26 \\
\hline Maizena dengan berat $200 \mathrm{~g}$ & $4,61 \mathrm{bc}$ & 1,31 \\
\hline Tapioka dengan berat $50 \mathrm{~g}$ & $8,06 \mathrm{~d}$ & 1,34 \\
\hline Tapioka dengan berat $100 \mathrm{~g}$ & $5,18 \mathrm{c}$ & 1,34 \\
\hline Tapioka dengan berat $150 \mathrm{~g}$ & $4,15 \mathrm{ab}$ & 1,29 \\
\hline Tapioka dengan berat $200 \mathrm{~g}$ & $4,02 \mathrm{ab}$ & 1,23 \\
\hline Keterangan : Angka rera yang & & $\mathrm{g}$ \\
\hline
\end{tabular}

Keterangan : Angka rerata yang diikuti dengan huruf yang sama pada kolom yang sama tidak berbeda nyata pada uji Duncan $1 \%$

Tabel 7 menunjukkan uji DMRT $(\alpha=0,01)$ perlakuan terbaik kadar protein diperoleh dari terigu dengan berat $100 \mathrm{~g}$ sebesar $11,22 \%$ dan sangat berbeda nyata dengan yang lain. Grafik rerata kadar protein pada berbagai perlakuan jenis tepung dan berat disajikan pada Gambar 2.

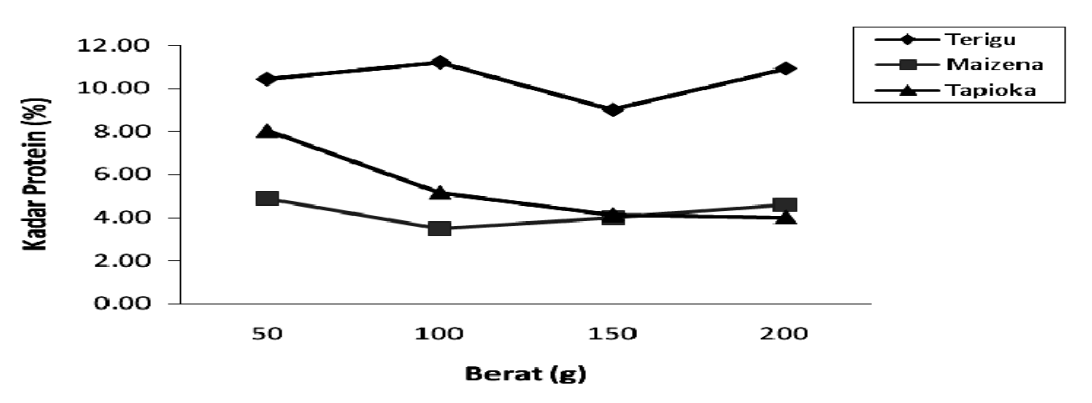

Gambar 2. Grafik rerata Kadar Protein (\%) pada Berbagai Perlakuan 


\begin{abstract}
Gambar 2 menunjukkan bahwa kadar protein tertinggi diperoleh pada perlakuan terigu dengan berat $100 \mathrm{~g}$ sebesar 11,22\% dan terendah pada maizena dengan berat $100 \mathrm{~g}$ sebesar 3,49\%. Rendahnya kadar protein pada kaldu dipengaruhi oleh hilangnya protein selama proses pemanasan. Winarno (2003) menyatakan bahwa pemanasan yang dilakukan secara berlebihan atau waktu yang lama tanpa penambahan karbohidrat, dapat mengakibatkan nilai gizi protein akan berkurang karena terbentuknya ikatan silang dalam protein. Protein merupakan senyawa yang reaktif terhadap panas dimana sisi aktif beberapa asam amino dapat bereaksi dengan komponen lain misalnya lemak. Peran tepung terigu lebih dominan dalam peningkatan kadar protein karena tepung terigu masih mengandung gluten.
\end{abstract}

\subsubsection{Kadar Lemak}

Lemak merupakan bagian terpenting dari semua bahan, lemak berperan dalam penambahan kalori serta memperbaiki tekstur dan citarasa bahan pangan (Winarno, 2003).

Rerata kadar lemak pada berbagai perlakuan antara jenis tepung dengan berat yang dihasilkan berkisar antara $1,21-9,57 \%$ (Lampiran 4).

Hasil analisis sidik ragam (Lampiran 4) menunjukkan bahwa adanya perbedaan jenis tepung dan berat serta interaksi antar perlakuan memberikan pengaruh sangat nyata $(\alpha$ $=0,01)$ terhadap kadar lemak. Rerata nilai kadar lemak pada berbagai perlakuan ditunjukkan pada Tabel 8 berikut.

Tabel 8. Rerata Kadar Lemak (\%) pada Berbagai Perlakuan

\begin{tabular}{|l|c|c|}
\hline \multicolumn{1}{|c|}{ Perlakuan } & $\begin{array}{c}\text { Rerata } \\
\text { Kadar Lemak (\%) }\end{array}$ & $\begin{array}{c}\text { DMRT } \\
(\boldsymbol{\alpha = 0 , 0 1 )}\end{array}$ \\
\hline Terigu dengan berat 50 g & $9,57 \mathrm{~g}$ & - \\
\hline Terigu dengan berat 100 g & $7,24 \mathrm{f}$ & 1,40 \\
\hline Terigu dengan berat 150 g & $4,69 \mathrm{de}$ & 1,39 \\
\hline Terigu dengan berat $200 \mathrm{~g}$ & $3,57 \mathrm{c}$ & 1,34 \\
\hline Maizena dengan berat 50 g & $2,51 \mathrm{c}$ & 1,31 \\
\hline Maizena dengan berat 100 g & $3,92 \mathrm{cde}$ & 1,38 \\
\hline Maizena dengan berat 150 g & $4,90 \mathrm{e}$ & 1,40 \\
\hline Maizena dengan berat $200 \mathrm{~g}$ & $4,33 \mathrm{de}$ & 1,39 \\
\hline Tapioka dengan berat 50 g & $4,74 \mathrm{e}$ & 1,40 \\
\hline Tapioka dengan berat 100 g & $2,42 \mathrm{~b}$ & 1,28 \\
\hline Tapioka dengan berat 150 g & $1,21 \mathrm{a}$ & 1,22 \\
\hline
\end{tabular}




\begin{tabular}{|l|c|c|}
\hline Tapioka dengan berat $200 \mathrm{~g}$ & $3,86 \mathrm{~cd}$ & 1,36 \\
\hline
\end{tabular}

Keterangan : Angka rerata yang diikuti dengan huruf yang sama pada kolom yang sama tidak berbeda nyata pada uji Duncan $1 \%$

Tabel 8 menunjukkan uji DMRT $(\alpha=0,01)$ perlakuan terbaik kadar lemak diperoleh dari tapioka dengan berat $150 \mathrm{~g}$ sebesar $1,21 \%$ dan sangat berbeda nyata dengan yang lain. Sudarmadji (1989) menyatakan bahwa hasil hidrolisis lemak berupa asam lemak dan gliserol. Reaksi hidrolisis mengakibatkan kerusakan lemak, hal ini terjadi karena terdapat sejumlah air dalam lemak tersebut.

Grafik rerata kadar lemak pada berbagai perlakuan jenis tepung dan berat disajikan pada Gambar 3 .
Pada gambar tersebut menunjukkan bahwa kadar lemak tertinggi diperoleh pada perlakuan terigu dengan berat $50 \mathrm{~g}$ sebesar $9,57 \%$ dan terendah pada tapioka dengan berat $150 \mathrm{~g}$ sebesar $1,21 \%$. Tepung tapioka berpengaruh pada daya serap lemak karena tepung tapioka terdiri dari granula-granula pati yang banyak terdapat di dalam sel umbi ketela pohon dan sebagai karbohidrat dengan bagian terbesar selain protein, lemak dan komponen lainnya (Utomo, 2007).

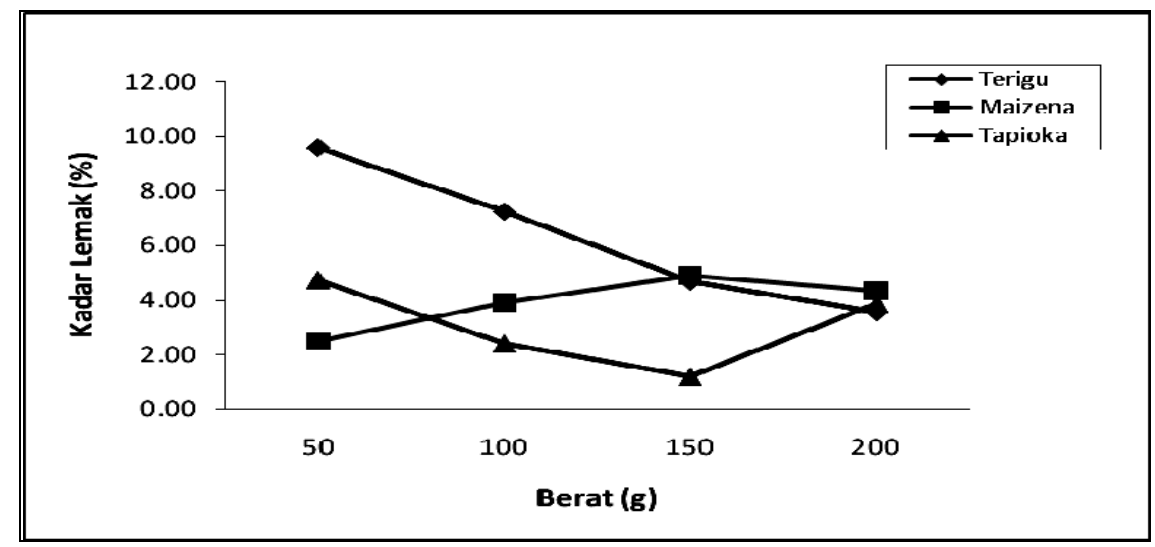

Gambar 3. Grafik rerata Kadar Lemak (\%) pada Berbagai Perlakuan

Kadar lemak juga sangat dipengaruhi oleh adanya kandungan air dalam bahan karena air merupakan faktor yang berperan sangat besar pada saat proses oksidasi lemak dan juga reaksi yang berkaitan dengan radikal bebas (Kumalaningsih, 1990). Pada dasarnya peningkatan kadar air akan mengencerkan konsentrasi bahan yang akan bereaksi sehingga air dapat memperlambat reaksi oksidasi lemak atau reaksi antara 
lemak dan protein sampai pada suatu titik dimana kisaran kadar air yang sedang "Intermediate" tercapai (Kumalaningsih, 1990).

\subsubsection{Intensitas Warna (kekuningan/b*)}

Warna makanan memiliki peranan utama dalam penampilan makanan, meskipun makanan tersebut lezat, tetapi bila penampilan tidak menarik waktu disajikan akan mengakibatkan selera orang yang akan memakannya menjadi hilang (Moehyi, 2002). Warna biasanya merupakan tanda kemasakan atau kerusakan dari makanan, seperti perlakuan penyimpanan yang memungkinkan terjadinya perubahan warna. Oleh karena itu untuk mendapatkan warna yang sesuai dan menarik harus digunakan teknik memasak tertentu atau dengan penyimpanan yang baik.

Warna perlakuan antara jenis tepung dengan berat diukur menggunakan alat coloreader mode CR-10 dengan metode pengukuran warna sistem hunter, sedangkan parameter yang dibaca adalah nilai
$L^{*}, a^{*}$ dan $b^{*}$. Nilai $L^{*}$ berkisar antara 0 sampai 100 , nilai $\mathrm{L}=0$ menunjukkan tingkat kecerahan sangat gelap (hitam) dan nilai $\mathrm{L}=100$ sangat cerah (putih). a* mempunyai kisaran nilai -100 sampai +100 , nilai negatif (-) menyatakan kecenderungan warna hijau dan nilai positif $(+)$ kecenderungan warna merah. Nilai $b^{*}$ berkisar antara -100 sampai +100, nilai negatif (-) menyatakan kecenderungan warna biru dan nilai positif (+) kecenderungan warna kuning. Rerata kadar warna kekuningan $\left(b^{*}\right)$ pada berbagai perlakuan antara jenis tepung dengan berat yang dihasilkan berkisar antara 2,12 - 3,65 (Lampiran 5). Hasil analisis sidik ragam (Lampiran 5) menunjukkan bahwa adanya perbedaan jenis tepung dan berat serta interaksi perlakuan memberikan pengaruh sangat nyata $(\alpha=0,01)$ terhadap warna kekuningan $\left(b^{*}\right)$. Rerata nilai warna kekuningan $\left(b^{*}\right)$ pada berbagai perlakuan ditunjukkan pada Tabel 9.

Tabel 9. Rerata Warna kekuningan (b*) pada Berbagai Perlakuan

\begin{tabular}{|l|c|c|}
\hline \multicolumn{1}{|c|}{ Perlakuan } & $\begin{array}{c}\text { Rerata } \\
\text { Warna kekuningan (b*) }\end{array}$ & $\begin{array}{c}\text { DMRT } \\
(\boldsymbol{\alpha = 0 , 0 1 )}\end{array}$ \\
\hline Terigu dengan berat $50 \mathrm{~g}$ & $2,17 \mathrm{a}$ & 0,27 \\
\hline Terigu dengan berat $100 \mathrm{~g}$ & $2,31 \mathrm{~b}$ & 0,28 \\
\hline Terigu dengan berat $150 \mathrm{~g}$ & $2,13 \mathrm{a}$ & 0,26 \\
\hline Terigu dengan berat $200 \mathrm{~g}$ & $3,65 \mathrm{f}$ & - \\
\hline Maizena dengan berat $50 \mathrm{~g}$ & $2,67 \mathrm{~d}$ & 0,28 \\
\hline Maizena dengan berat $100 \mathrm{~g}$ & $2,55 \mathrm{c}$ & 0,28 \\
\hline
\end{tabular}




\begin{tabular}{|l|c|c|}
\hline Maizena dengan berat $150 \mathrm{~g}$ & $2,76 \mathrm{de}$ & 0,28 \\
\hline Maizena dengan berat $200 \mathrm{~g}$ & $2,93 \mathrm{ef}$ & 0,28 \\
\hline Tapioka dengan berat $50 \mathrm{~g}$ & $2,89 \mathrm{e}$ & 0,28 \\
\hline Tapioka dengan berat $100 \mathrm{~g}$ & $2,85 \mathrm{e}$ & 0,28 \\
\hline Tapioka dengan berat $150 \mathrm{~g}$ & $2,30 \mathrm{~b}$ & 0,28 \\
\hline Tapioka dengan berat $200 \mathrm{~g}$ & $2,12 \mathrm{a}$ & 0,25 \\
\hline
\end{tabular}

Keterangan : Angka rerata yang diikuti dengan huruf yang sama pada kolom yang sama tidak berbeda nyata pada uji Duncan $1 \%$

Tabel 9 menunjukkan uji DMRT $(\alpha=0,01)$ perlakuan terbaik warna kekuningan ( $\left.b^{*}\right)$ diperoleh dari terigu dengan berat $200 \mathrm{~g}$ sebesar 3,65 dan sangat berbeda nyata dengan yang lain. Grafik rerata warna kekuningan $\left(b^{*}\right)$ pada berbagai perlakuan jenis tepung dan berat disajikan pada Gambar 4.

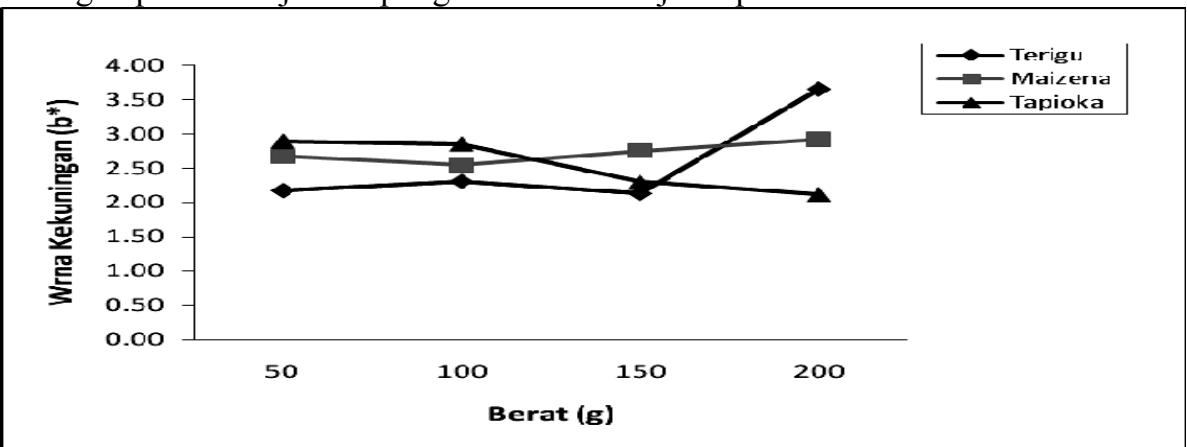

Gambar 4. Grafik rerata Warna kekuningan (b*) pada Berbagai Perlakuan

Gambar 4 menunjukkan bahwa kadar warna kekuningan $\left(b^{*}\right)$ tertinggi diperoleh pada perlakuan terigu dengan berat $200 \mathrm{~g}$ sebesar 3,65 dan terendah pada tapioka dengan berat $200 \mathrm{~g}$ sebesar 2,12. Semakin tinggi rerata rangking kesukaan panelis, maka tingkat kesukaan panelis terhadap warna kaldu ayam instan semakin besar. Perubahan warna selama proses pemanasan juga dipengaruhi adanya kandungan minyak (kaldu) dalam bahan dimana warna minyak dipengaruhi oleh pigmen terlarut dalam minyak (kaldu). Warna kuning disebabkan adanya pigmen karotin yang larut dalam kaldu serta adanya pelepasan molekul karbohidrat dan protein karena aktivitas enzim seperti peroksidase, polipeptidase dan oksidase (Kumalaningsih, 1990).

\subsubsection{Pemilihan Alternatif Terbaik} Tahap I

Penentuan perlakuan terbaik jenis tepung dengan berat pada penelitian tahap I dilakukan dengan 
menggunakan metode indeks efektivitas (De Garmo, Sullivan dan Canada, 1984). Metode ini dilakukan pada parameter fisik dan kimia. Parameter kimia meliputi, kadar air, kadar protein, kadar lemak dan warna kekuningan $\left(b^{*}\right)$. Penilaian perlakuan terbaik disajikan pada Tabel 10.

Hasil perhitungan (Lampiran

7) menunjukkan perlakuan terbaik pada tahap I untuk parameter fisik dan kimia antara jenis tepung dengan berat diperoleh dari perlakuan terigu dengan berat $100 \mathrm{~g}$ dengan karakteristik sebagai berikut: kadar air 5,93\%; kadar protein 11,22\%; kadar lemak 7,24\% dan warna kekuningan (b*) 2,31.

Tabel 10. Penilaian Perlakuan Terbaik terhadap Parameter Fisik dan Kimia pada Berbagai Perlakuan

\begin{tabular}{|l|c|c|c|c|c|}
\hline \multicolumn{1}{|c|}{ Perlakuan } & $\begin{array}{c}\text { Kadar } \\
\text { air (\%) }\end{array}$ & $\begin{array}{c}\text { Kadar } \\
\text { Protein } \\
\mathbf{( \% )}\end{array}$ & $\begin{array}{c}\text { Kadar } \\
\text { Lemak } \\
\mathbf{( \% )}\end{array}$ & b* & $\begin{array}{c}\text { Nilai } \\
\text { Produk }\end{array}$ \\
\hline Terigu dengan berat 50 g & 3,96 & 10,44 & 9,57 & 2,17 & 0,466 \\
\hline Terigu dengan berat 100 g & 5,93 & 11,22 & 7,24 & 2,31 & $0,63 *^{*}$ \\
\hline Terigu dengan berat 150 g & 4,40 & 9,01 & 4,69 & 2,13 & 0,333 \\
\hline Terigu dengan berat 200 g & 4,71 & 10,93 & 3,57 & 3,65 & 0,566 \\
\hline Maizena dengan berat 50 g & 4,94 & 4,91 & 2,51 & 2,67 & 0,234 \\
\hline Maizena dengan berat 100 g & 7,80 & 3,49 & 3,92 & 2,55 & 0,470 \\
\hline Maizena dengan berat 150 g & 5,27 & 4,02 & 4,90 & 2,76 & 0,298 \\
\hline Maizena dengan berat 200 g & 4,84 & 4,61 & 4,33 & 2,93 & 0,284 \\
\hline Tapioka dengan berat 50 g & 6,11 & 8,06 & 4,74 & 2,89 & 0,538 \\
\hline Tapioka dengan berat 100 g & 5,64 & 5,18 & 2,42 & 2,85 & 0,326 \\
\hline Tapioka dengan berat 150 g & 4,67 & 4,15 & 1,21 & 2,30 & 0,110 \\
\hline Tapioka dengan berat 200 g & 5,26 & 4,02 & 3,86 & 2,12 & 0,205 \\
\hline SNI Kaldu ayam & & 0,02 & 0,3 & & \\
\hline
\end{tabular}

$*=$ perlakuan terbaik

\subsection{Penelitian Tahap II : Pengaruh Proporsi Brokoli Terhadap Kualitas Kaldu Ayam Dan Brokoli Instan}

Penelitian Tahap II adalah pembuatan kaldu ayam dan brokoli instan, dimana hasil perlakuan terbaik pada Tahap I dilanjutkan dengan penambahan berat brokoli yang berbeda-beda. Pengamatan Pada tahap ini meliputi, kadar air, kadar antioksidan, kadar protein, kadar lemak dan kadar serat kasar.

\subsubsection{Kadar Air}


Rerata kadar air pada berbagai perlakuan antara terigu 100 g dengan berat brokoli, yang dihasilkan berkisar 3,49-11,22\% (Lampiran 8). Hasil analisis sidik ragam (Lampiran 8) menunjukkan bahwa adanya pengaruh yang sangat nyata antara terigu $100 \mathrm{~g}$ dengan berat brokoli (BNT 5\%) terhadap kadar air. Rerata nilai kadar air pada berbagai perlakuan ditunjukkan pada Tabel 11.

Tabel 11. Rerata Kadar Air (\%) pada Berbagai Perlakuan

\begin{tabular}{|l|c|c|}
\multicolumn{1}{|c|}{ Perlakuan } & $\begin{array}{c}\text { Rerata } \\
\text { Kadar Air (\%) }\end{array}$ & \multirow{2}{*}{ BNT 5\% } \\
\cline { 1 - 2 } Terigu 100 g dengan brokoli 50 g & $3,96 \mathrm{a}$ & \multirow{2}{*}{0,68} \\
\cline { 1 - 2 } Terigu 100 g dengan brokoli 100 g & $4,40 \mathrm{ab}$ & \\
\hline Terigu 100 g dengan brokoli 150 g & $4,64 \mathrm{ab}$ & \\
\hline Terigu 100 g dengan brokoli 200 g & $4,71 \mathrm{ab}$ & \\
\cline { 1 - 2 } Terigu 100 g dengan brokoli 250 g & $5,93 \mathrm{~b}$ & \\
\hline
\end{tabular}

Keterangan: Angka rerata yang diikuti dengan huruf yang sama pada kolom yang sama tidak berbeda nyata pada uji Duncan 1\%

Tabel 11 menunjukkan uji BNT 5\% perlakuan terbaik kadar air diperoleh dari terigu $100 \mathrm{~g}$ dengan brokoli $50 \mathrm{~g}$ sebesar $36,96 \%$ dan sangat berbeda nyata dengan yang lain. Grafik rerata kadar air pada berbagai perlakuan antara terigu $100 \mathrm{~g}$ dengan berat brokoli disajikan pada Gambar 5.

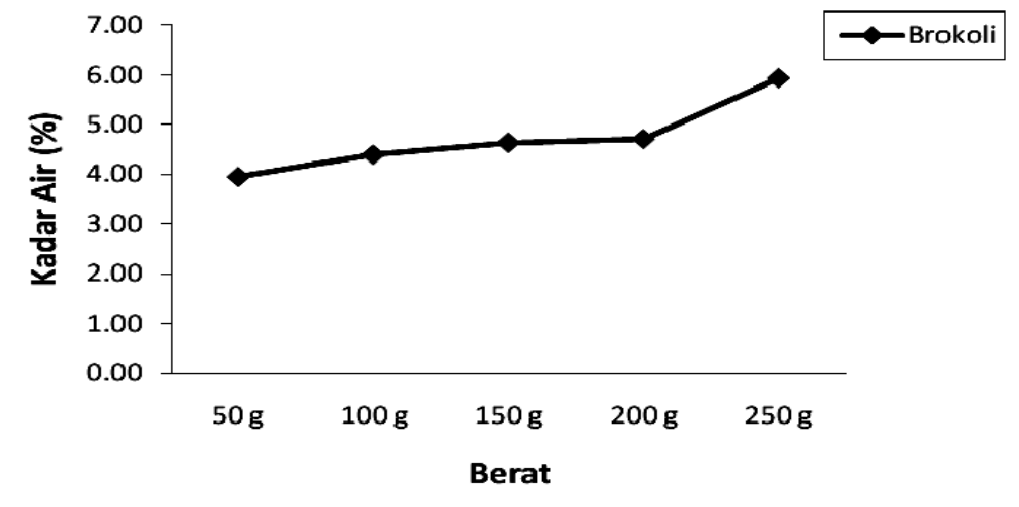

Gambar 5. Grafik rerata Kadar Air (\%) pada Berbagai Perlakuan 

Gambar 5 menunjukkan bahwa kadar air tertinggi diperoleh pada perlakuan terigu $100 \mathrm{~g}$ dengan brokoli 250 g sebesar 5,93\% dan terendah pada terigu $100 \mathrm{~g}$ dengan brokoli $50 \mathrm{~g}$ sebesar 3,96\%. Dari hasil analisa tersebut ada kecenderungan kadar air meningkat seiring dengan penambahan berat brokoli, hal ini karena brokoli memiliki kandungan air yang cukup tinggi sehingga bila tidak dikontrol maka nantinya dapat memperpendek umur simpan akibat adanya jamur yang dapat masuk ke produk. Kumalaningsih (1990) menyatakan bahwa air dalam produk pangan atas dasar keterikatannya dapat dibedakan menjadi : (1) Air bebas, yaitu air yang ada di permukaan, tidak terikat dengan molekul lain sehingga mudah diuapkan. (2) Air terikat secara fisik, yaitu yang terikat dengan sistem kapiler atau air absorbsi dan (3) Air yang terikat secara kimia, misalnya air kristal dan air yang terikat dalam sistem dispersi. Adanya senyawa yang terlarut dalam produk pangan mempunyai ikatan yang erat dengan aktivitas air $\left(\mathrm{A}_{\mathrm{w}}\right)$, yang merupakan banyaknya air bebas yang memungkinkan adanya suatu proses kehidupan.

\subsubsection{Kadar Antioksidan}

Rerata kadar antioksidan pada berbagai perlakuan antara terigu $100 \mathrm{~g}$ dengan berat brokoli, yang dihasilkan berkisar 8,95 - 42,70\% (Lampiran 9). Hasil analisis sidik ragam (Lampiran 9) menunjukkan bahwa adanya pengaruh yang sangat nyata antara terigu $100 \mathrm{~g}$ dengan berat brokoli (BNT 5\%) terhadap kadar antioksidan. Rerata nilai kadar antioksidan pada berbagai perlakuan ditunjukkan pada Tabel 12.

Tabel 12 menunjukkan uji BNT 5\% perlakuan terbaik kadar antioksidan diperoleh dari terigu 100 g dengan brokoli $250 \mathrm{~g}$ sebesar $42,70 \%$ dan sangat berbeda nyata dengan yang lain.

Tabel 12. Rerata Kadar Antioksidan (\%) pada Berbagai Perlakuan

\begin{tabular}{|l|c|c|}
\hline \multicolumn{1}{|c|}{ Perlakuan } & $\begin{array}{c}\text { Rerata } \\
\text { Kadar Antioksidan (\%) }\end{array}$ & \multirow{2}{*}{ BNT 5\% } \\
\cline { 1 - 2 } Terigu 100 g dengan brokoli 50 g & $8,95 \mathrm{a}$ & \multirow{2}{*}{2,34} \\
\cline { 1 - 2 } Terigu 100 g dengan brokoli 100 g & $12,36 \mathrm{~b}$ & \\
\cline { 1 - 2 } Terigu 100 g dengan brokoli 150 g & $22,09 \mathrm{c}$ & \\
\hline Terigu 100 g dengan brokoli 200 g & $34,00 \mathrm{~d}$ & \\
\cline { 1 - 2 } Terigu 100 g dengan brokoli 250 g & $42,70 \mathrm{e}$ & \\
\hline
\end{tabular}

Keterangan : Angka rerata yang diikuti dengan huruf yang sama pada kolom yang sama tidak berbeda nyata pada uji Duncan $1 \%$ 


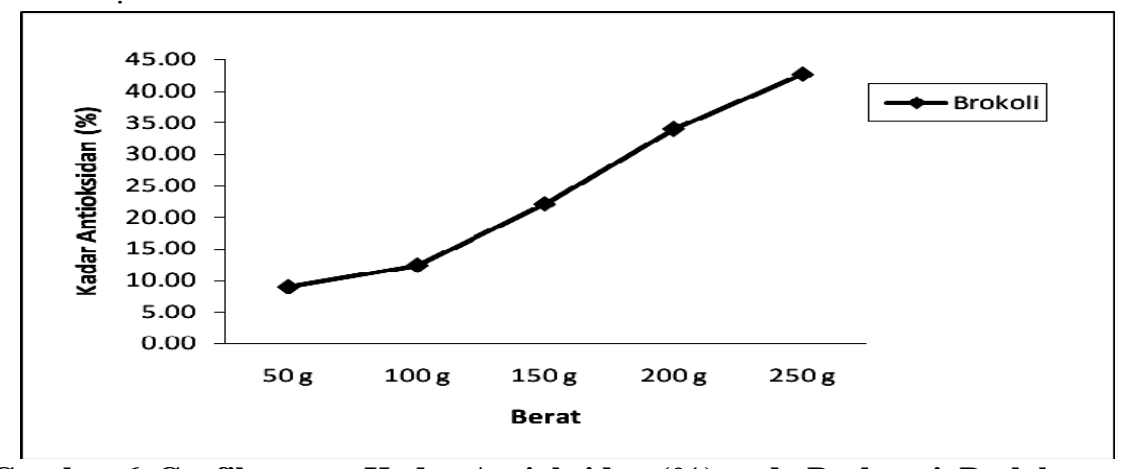

Gambar 6. Grafik rerata Kadar Antioksidan (\%) pada Berbagai Perlakuan

\begin{abstract}
Grafik rerata kadar antioksidan pada berbagai perlakuan antara terigu $100 \mathrm{~g}$ dengan berat brokoli yang disajikan pada Gambar 6. menunjukkan bahwa kadar antioksidan tertinggi diperoleh pada perlakuan terigu $100 \mathrm{~g}$ dengan brokoli $250 \mathrm{~g}$ sebesar $42,70 \%$ dan terendah pada terigu $100 \mathrm{~g}$ dengan brokoli $50 \quad \mathrm{~g}$ sebesar $8,95 \%$. Kandungan antioksidan yang terdapat dalam produk ada kecenderungan naik pada penambahan proporsi brokoli, hal ini karena semakin banyak brokoli yang ditambahkan maka kandungan antioksidan dalam bahan tersebut semakin meningkat. Hal yang perlu dilakukan untuk penelitian lanjutan adalah seberapa besar proporsi brokoli yang diberikan sampai kandungan antioksidannya optimal.
\end{abstract}

Semakin meningkatnya proporsi brokoli yang ditambahkan, maka kadar antioksidannya juga meningkat, hal ini karena adanya tepung yang berfungsi mengikat zat antioksidan dalam brokoli.

\subsubsection{Kadar Protein}

Rerata kadar protein pada berbagai perlakuan antara terigu $100 \mathrm{~g}$ dengan berat brokoli yang dihasilkan berkisar antara 8,95 $42,70 \%$ (Lampiran 10). Hasil analisis sidik ragam (Lampiran 10) menunjukkan bahwa adanya pengaruh yang sangat nyata antara terigu $100 \mathrm{~g}$ dengan berat brokoli (BNT 5\%) terhadap kadar protein. Rerata nilai kadar protein pada berbagai perlakuan ditunjukkan pada Tabel 13. 
Tabel 13. Rerata Kadar Protein (\%) pada Berbagai Perlakuan

\begin{tabular}{|c|c|c|}
\hline Perlakuan & $\begin{array}{c}\text { Rerata } \\
\text { Kadar Protein (\%) }\end{array}$ & BNT 5\% \\
\hline Terigu $100 \mathrm{~g}$ dengan brokoli $50 \mathrm{~g}$ & $14,06 \mathrm{a}$ & \multirow{5}{*}{1,16} \\
\hline Terigu $100 \mathrm{~g}$ dengan brokoli $100 \mathrm{~g}$ & $14,21 \mathrm{a}$ & \\
\hline Terigu $100 \mathrm{~g}$ dengan brokoli $150 \mathrm{~g}$ & $16,17 \mathrm{bc}$ & \\
\hline Terigu $100 \mathrm{~g}$ dengan brokoli $200 \mathrm{~g}$ & $14,07 \mathrm{a}$ & \\
\hline Terigu $100 \mathrm{~g}$ dengan brokoli $250 \mathrm{~g}$ & $16,60 \mathrm{~b}$ & \\
\hline
\end{tabular}

Keterangan : Angka rerata yang diikuti dengan huruf yang sama pada kolom yang sama tidak berbeda nyata pada uji Duncan $1 \%$

Tabel 13 menunjukkan uji BNT 5\% perlakuan terbaik kadar protein diperoleh dari terigu $100 \mathrm{~g}$ dengan brokoli $150 \mathrm{~g}$ sebesar $16,17 \%$ dan sangat berbeda nyata dengan yang lain. Grafik rerata kadar protein pada berbagai perlakuan antara terigu $100 \mathrm{~g}$ dengan berat brokoli disajikan pada Gambar 7 .

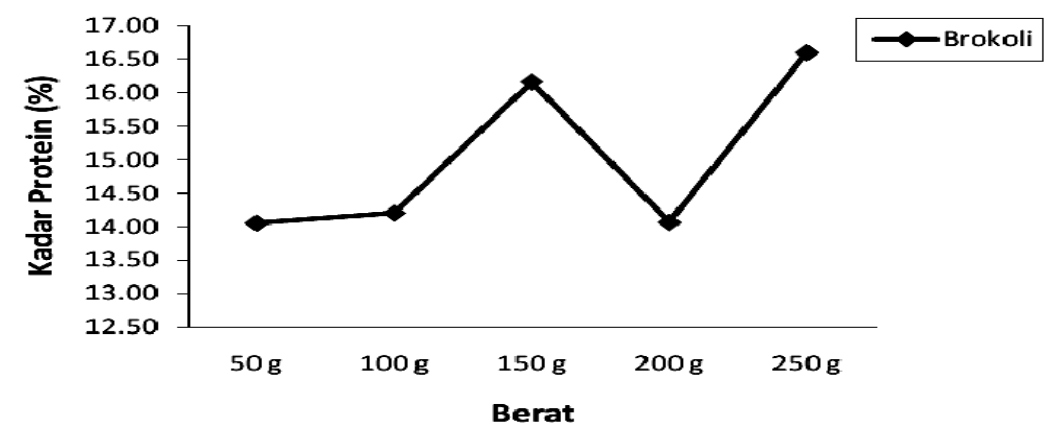

Gambar 7. Grafik rerata Kadar Protein (\%) pada Berbagai Perlakuan

Gambar 7 menunjukkan bahwa kadar protein tertinggi diperoleh pada perlakuan terigu 100 $\mathrm{g}$ dengan brokoli $150 \mathrm{~g}$ sebesar $16,17 \%$ dan terendah pada terigu $100 \mathrm{~g}$ dengan brokoli $50 \mathrm{~g}$ sebesar $14,06 \%$. Kandungan protein yang meningkat seiring dengan pertambahan proporsi brokoli mengidentifikasikan bahwa kandungan protein pada bahan brokoli tinggi sehingga mempengaruhi kandungan protein produk jadi. Wirakusuma (2005) menyatakan bahwa kandungan protein pada brokoli berkisar 2,1 gr tiap 100 gr bahan yang dapat dimakan. Margiono (1993) dalam 
Rindiani (2007) menyatakan bahwa lemak berinteraksi dengan protein dalam suatu emulsi. Protein berperan sebagai emulsifier pada interaksi antara lemak dan air. Globula lemak terpisah saat pengadukan dalam air, maka globula lemak yang terdispersi terselubungi oleh protein, dimana bagian non polar protein terikat pada bagian luar globula lemak, sedangkan bagian polar protein terikat ke air.

\subsubsection{Kadar Lemak}

Rerata kadar lemak pada berbagai perlakuan antara terigu $100 \mathrm{~g}$ dengan berat brokoli yang dihasilkan berkisar antara 3,10 5,43\% (Lampiran 11). Hasil analisis sidik ragam (Lampiran 11) menunjukkan bahwa adanya pengaruh yang sangat nyata antara terigu $100 \mathrm{~g}$ dengan berat brokoli (BNT 5\%) terhadap kadar lemak. Rerata nilai kadar lemak pada berbagai perlakuan ditunjukkan pada Tabel 14. Tabel 14 menunjukkan uji BNT 5\% perlakuan terbaik kadar lemak diperoleh dari terigu $100 \mathrm{~g}$ dengan brokoli 200 g sebesar 3,10\% dan sangat berbeda nyata dengan yang lain.

Tabel 14. Rerata Kadar Lemak (\%) pada Berbagai Perlakuan

\begin{tabular}{|l|c|c|}
\hline \multicolumn{1}{|c|}{ Perlakuan } & $\begin{array}{c}\text { Rerata } \\
\text { Kadar Lemak (\%) }\end{array}$ & \multirow{2}{*}{ BNT 5\% } \\
\hline Terigu 100 g dengan brokoli 50 g & $3,69 \mathrm{a}$ \\
\hline Terigu 100 g dengan brokoli 100 g & $3,53 \mathrm{a}$ \\
\cline { 1 - 2 } Terigu 100 g dengan brokoli 150 g & $4,04 \mathrm{ab}$ & \multirow{2}{*}{1,25} \\
\hline Terigu 100 g dengan brokoli 200 g & $3,10 \mathrm{a}$ & \\
\hline Terigu 100 g dengan brokoli 250 g & $5,43 \mathrm{~b}$ & \\
\hline
\end{tabular}

Keterangan : Angka rerata yang diikuti dengan huruf yang sama pada kolom yang sama tidak berbeda nyata pada uji Duncan 1\% 
Grafik rerata kadar lemak pada berbagai perlakuan antara terigu $100 \mathrm{~g}$ dengan berat brokoli disajikan pada Gambar 8 .

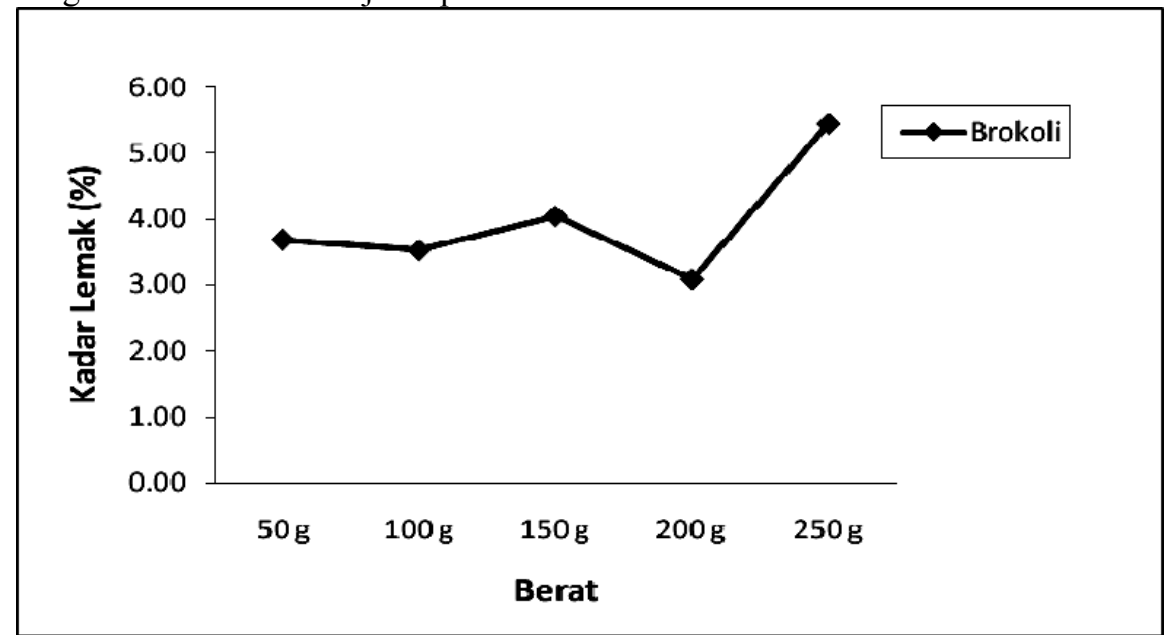

Gambar 8. Grafik rerata Kadar Lemak (\%) pada Berbagai Perlakuan

\begin{abstract}
Gambar 8 menunjukkan bahwa kadar lemak tertinggi diperoleh pada perlakuan terigu 100 $\mathrm{g}$ dengan brokoli $250 \mathrm{~g}$ sebesar $5,43 \%$ dan terendah pada terigu 100 g dengan brokoli $200 \mathrm{~g}$ sebesar $3,10 \%$. Kecenderungan peningkatan kadar lemak dikarenakan kondisi bahan pengikat berupa tepung berbasis karbohidrat sehingga kandungan lemak dalam brokoli tidak banyak keluar dan mengalami kerusakan.
\end{abstract}

\subsubsection{Kadar Serat Kasar}

Rerata kadar serat kasar pada berbagai perlakuan antara terigu $100 \mathrm{~g}$ dengan berat brokoli yang dihasilkan berkisar antara 1,07 - 2,15\% (Lampiran 12). Hasil analisis sidik ragam (Lampiran 12) menunjukkan bahwa adanya pengaruh yang sangat nyata antara terigu $100 \mathrm{~g}$ dengan berat brokoli (BNT 5\%) terhadap kadar serat kasar. Rerata nilai kadar serat kasar pada berbagai perlakuan ditunjukkan pada Tabel 15. 
Tabel 15. Rerata Kadar Serat kasar (\%) pada Berbagai Perlakuan

\begin{tabular}{|l|c|c|}
\hline \multicolumn{1}{|c|}{ Perlakuan } & $\begin{array}{c}\text { Rerata } \\
\text { Kadar Serat kasar (\%) }\end{array}$ & $\begin{array}{c}\text { BNT } \\
\mathbf{5 \%}\end{array}$ \\
\hline Terigu 100 g dengan brokoli 50 g & $1,07 \mathrm{a}$ & \multirow{2}{*}{1,25} \\
\cline { 1 - 2 } Terigu 100 g dengan brokoli 100 g & $1,24 \mathrm{a}$ & \\
\cline { 1 - 2 } Terigu 100 g dengan brokoli 150 g & $1,43 \mathrm{ab}$ & \\
\hline Terigu 100 g dengan brokoli 200 g & $1,12 \mathrm{a}$ & \\
\cline { 1 - 2 } Terigu 100 g dengan brokoli 250 g & $2,15 \mathrm{~b}$ & \\
\hline
\end{tabular}

Keterangan : Angka rerata yang diikuti dengan huruf yang sama pada kolom yang sama tidak berbeda nyata pada uji Duncan $1 \%$

Tabel 15 menunjukkan uji BNT 5\% perlakuan terbaik kadar serat kasar diperoleh dari terigu $100 \mathrm{~g}$ dengan brokoli $250 \mathrm{~g}$ sebesar 2,15\% dan sangat berbeda nyata dengan yang lain. Grafik rerata kadar serat kasar pada berbagai perlakuan antara terigu $100 \mathrm{~g}$ dengan berat brokoli disajikan pada Gambar 9 .

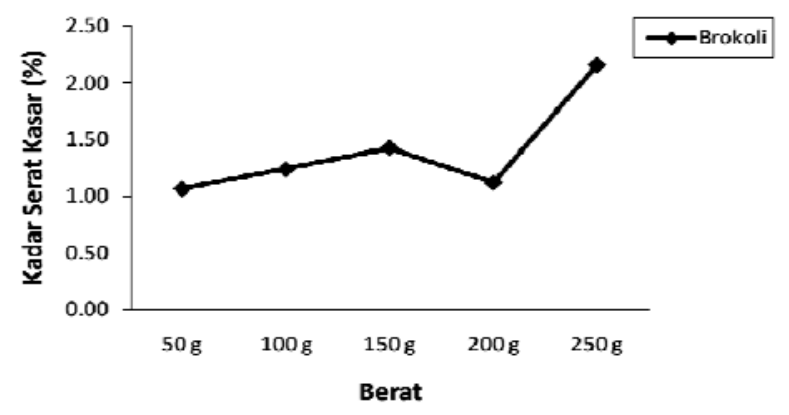

Gambar 9. Grafik rerata Kadar Serat Kasar (\%) pada Berbagai Perlakuan

Gambar 9 menunjukkan bahwa kadar serat kasar tertinggi diperoleh pada perlakuan terigu 100 $\mathrm{g}$ dengan brokoli $250 \mathrm{~g}$ sebesar $2,15 \%$ dan terendah pada terigu 100 $\mathrm{g}$ dengan brokoli $50 \mathrm{~g}$ sebesar $1,07 \%$. Berdasarkan hasil analisa menunjukkan rata-rata peningkatan serat kasar dengan penambahan proporsi brokoli, hal ini karena kandungan serat makanan pada brokoli tersedia dalam jumlah banyak (Anonymous, 2008) sehingga kandungan serat kasar bertambah seiring dengan jumlah brokoli yang ditambahkan.

\subsubsection{Pemilihan Alternatif Terbaik Tahap II}


Penentuan perlakuan

terbaik terigu $100 \mathrm{~g}$ dengan berat brokoli pada penelitian tahap II dilakukan dengan menggunakan metode indeks efektivitas (De Garmo, Sullivan dan Canada, 1984).
Metode ini dilakukan pada parameter kimia meliputi, kadar air, kadar protein, kadar lemak, kadar antioksidan dan kadar serat kasar. Penilaian perlakuan terbaik disajikan pada Tabel 16.

Tabel 16. Penilaian Perlakuan Terbaik terhadap Parameter Kimia pada Berbagai Perlakuan

\begin{tabular}{|c|c|c|c|c|c|c|}
\hline \multirow[b]{2}{*}{ Perlakuan } & \multicolumn{5}{|c|}{ Kualitas Kimia } & \multirow[b]{2}{*}{ Score } \\
\hline & $\begin{array}{c}\text { Kadar } \\
\text { Air } \\
(\%)\end{array}$ & $\begin{array}{c}\text { Lemak } \\
\text { (\%) }\end{array}$ & $\begin{array}{c}\text { Protein } \\
(\%)\end{array}$ & $\begin{array}{c}\text { Anti } \\
\text { Oksidan } \\
(\%) \\
\end{array}$ & $\begin{array}{l}\text { Serat } \\
\text { Kasar }\end{array}$ & \\
\hline Brokoli 50 g & 3.96 & 3.69 & 14.06 & 8.95 & 1.07 & 0,020 \\
\hline Brokoli 100 g & 4.40 & 3.53 & 14.21 & 12.36 & 1.24 & 0,136 \\
\hline Brokoli 150 g & 4.64 & 4.04 & 16.17 & 22.09 & 1.43 & 0,457 \\
\hline Brokoli 200 g & 4.71 & 3.10 & 14.07 & 34.00 & 1.12 & 0,306 \\
\hline Brokoli 250 g & 5.93 & 5.43 & 16.60 & 42.70 & 2.15 & $1,000 *$ \\
\hline
\end{tabular}

* = perlakuan terbaik

Hasil perhitungan
(Lampiran 14) menunjukkan perlakuan terbaik pada tahap II untuk parameter kimia antara terigu $100 \mathrm{~g}$ dengan berat brokoli diperoleh dari perlakuan terigu 100 g dengan brokoli $250 \mathrm{~g}$, dengan karakteristik sebagai berikut: kadar air 5,93\%; kadar antioksidan $42,70 \%$; kadar protein $16,60 \%$, kadar lemak 5,43\% dan kadar serat kasar 2,15\%.

\subsection{Uji Perbandingan Dengan Produk Lain}

Penelitian uji perbandingan dengan produk lain yaitu dengan uji organoleptik dengan membandingkan dengan produk kaldu "A" dan "B" rasa ayam. Sedangkan produk terbaik yang dihasilkan pada Tahap II ini dinamakan "Lezato" agar panelis tidak terpengaruh nama produk.

Pada tahap ini dilakukan perbandingan uji organoleptik dengan menggunakan uji Friedman yang meliputi warna, rasa dan aroma.

\subsubsection{Rasa}

Hasil uji organoleptik menunjukkan bahwa rerata ranking kesukaan panelis terhadap rasa ketiga produk ("Lezato", "A" dan 
"B") berkisar antara $3.45-5.3$ (Lampiran 15a). Semakin tinggi rerata ranking kesukaan panelis, maka tingkat kesukaan panelis terhadap rasa ketiga produk semakin besar.

Rerata nilai kesukaan panelis terhadap rasa pada ketiga produk mempunyai nilai terendah 3.45 didapatkan dari "Lezato" sedangkan nilai tertinggi 5.3 didapatkan dari "B". Hasil analisis Uji Friedman menunjukkan bahwa uji perbandingan pada tiga produk kaldu instan memberikan pengaruh nyata terhadap rerata kesukaan rasa kaldu instant. Tingkat kesukaan rasa tertinggi diperoleh dari kaldu instan "B".

\subsubsection{Warna}

Hasil uji organoleptik menunjukkan bahwa rerata ranking kesukaan panelis terhadap warna ketiga produk ("Lezato", "A" dan "B") berkisar antara 2.75 - 4.9. Semakin tinggi rerata ranking kesukaan panelis, maka tingkat kesukaan panelis terhadap warna ketiga produk semakin besar.

Rerata nilai kesukaan panelis terhadap warna ketiga produk mempunyai nilai terendah 2.75 didapatkan dari " $\mathrm{A}$ " sedangkan nilai tertinggi 4.9 didapatkan dari
"Lezato". Hasil analisis Uji Friedman menunjukkan bahwa uji perbandingan pada tiga produk kaldu instan memberikan pengaruh nyata terhadap rerata kesukaan warna kaldu instan. perlakuan terbaik tingkat kesukaan warna diperoleh dari kaldu instan "Lezato".

\subsubsection{Aroma}

Hasil uji organoleptik menunjukkan bahwa rerata ranking kesukaan panelis terhadap aroma ketiga produk ("Lezato", "A" dan "B") berkisar antara $3.2-4.95$. Semakin tinggi rerata ranking kesukaan panelis, maka tingkat kesukaan panelis terhadap aroma ketiga produk semakin besar.

Rerata nilai kesukaan panelis terhadap aroma ketiga produk mempunyai nilai terendah 3.2 didapatkan dari "Lezato" dan "A", sedangkan nilai tertinggi 4.95 didapatkan dari "B".

Hasil analisis Uji Friedman menunjukkan bahwa uji perbandingan pada tiga produk kaldu instan memberikan pengaruh nyata terhadap rerata kesukaan aroma kaldu instant. perlakuan terbaik tingkat kesukaan aroma diperoleh dari kaldu instan " $\mathrm{B}$ ". 


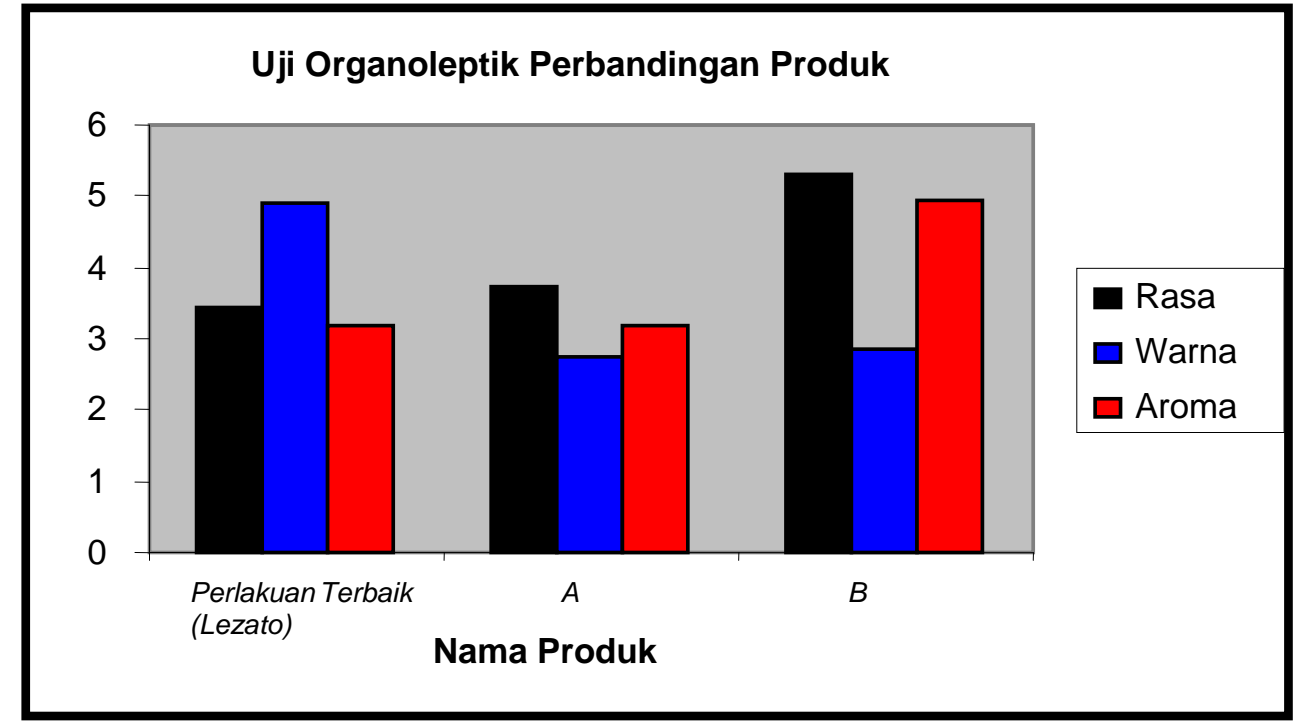

Gambar 13. Rerata Uji Organoleptik terhadap Rasa, Warna Dan Aroma pada "Lezato", “A” dan "B”

Penentuan perlakuan terbaik tiga jenis produk kaldu instan pada penelitian perbandingan produk dilakukan dengan menggunakan metode indeks efektivitas (De Garmo, Sullivan dan Canada, 1984). Metode ini dilakukan pada parameter organoleptik meliputi, rasa, warna dan aroma. Penilaian perlakuan terbaik disajikan pada Tabel 17.

Tabel 17. Penilaian Perlakuan Terbaik terhadap Parameter Organoleptik pada Perlakuan Terbaik (“Lezato"), “A” dan "B”

\begin{tabular}{|l|c|}
\hline \multicolumn{1}{|c|}{ Produk Kaldu Instan } & Nilai Produk \\
\hline Perlakuan Terbaik ("Lezato") & 0,350 \\
\hline "A" & 0,042 \\
\hline "B" & $0,666^{*}$ \\
\hline
\end{tabular}

$*=$ perlakuan terbaik 
Hasil perhitungan menunjukkan perlakuan terbaik pada tahap III untuk parameter organoleptik ketiga produk diperoleh dari " $\mathrm{B}$ " dengan rerata tingkat kesukaan panelis terhadap warna 2.85 ; rasa 5.3 dan aroma 4.95

\subsection{Prakiraan Analisa Biaya Produksi Kaldu Ayam Brokoli Instan}

produksi meliputi perancangan proses produksi, perancangan dan peralatan, penjadwalan produksi, dan perhitungan analisis finansial yang meliputi kebutuhan modal, biaya operasional, penetapan harga jual dan analisis Break Even Point (BEP), serta analisis kelayakan investasi yang meliputi perhitungan Payback Periode (PP), Net Present Value (NPV), dan Profitability Index (PI).

\subsubsection{Perancangan Kapasitas Produksi}

Kapasitas produksi suatu pabrik dapat ditentukan dengan dua pendekatan. Pendekatan pertama adalah dengan memperkirakan tingkat permintaan potensial terhadap produk pada masa depan. Pendekatan kedua dengan memperhatikan ketersediaan bahan bakunya . Pendekatan yang digunakan tergantung pada data yang tersedia.

Berdasarkan perhitungan penentuan kapasitas produksi didapatkan kapasitas produksi per hari sebesar 66,92 $\mathrm{kg}$, sedangkan kapasitas produksi per tahunnya sebesar $20.076 \mathrm{~kg}$, dengan asumsi 1 tahun 300 hari.

\subsubsection{Bahan Baku, Bahan Pembantu dan Bahan Pengemas}

Bahan baku adalah bahan utama yang dibutuhkan untuk suatu proses produksi. Bahan baku utama untuk pembuatan produk kaldu instan adalah kepala dan kaki ayam, terigu dan brokoli.

Bahan pembantu adalah bahan-bahan lain yang dibutuhkan dalam proses produksi selain bahan baku. Bahan pembantu yang digunakan untuk unit pengolahan pembuatan produk kaldu instan adalah bawang putih, garam dan air.

Bahan pengemas yang digunakan ada dua yaitu plastik alumunium sebagai pengemas primer dan kotak kardus sebagai pengemas sekunder. Plastik alumunium yang digunakan berukuran 5 gram. Plastik yang digunakan harus bersih, tidak bocor dan tidak cacat/rusak.

\subsubsection{Mesin dan Peralatan}

Mesin dan peralatan merupakan alat bantu yang sangat dibutuhkan oleh suatu industri/pabrik untuk menjalankan aktivitasnya terutama dalam proses produksi. Tersedianya mesin dan peralatan yang memadai akan membantu kerja manusia khususnya membantu kelancaran dan keberhasilan proses produksi.

Menurut Husnan dan Suwarsono (1994), patokan umum yang dapat digunakan dalam 
pemilihan jenis teknologi adalah seberapa jauh derajat mekanisasi yang diinginkan dan manfaat ekonomi yang diharapkan. Selain itu terdapat kriteria yang lain, yaitu :

- Ketepatan jenis teknologi yang dipilih dengan bahan mentah yang digunakan

- Keberhasilan penggunaan jenis teknologi tersebut di tempat lain yang memiliki ciri-ciri yang mendekati dengan lokasi proyek

- Kemampuan pengetahuan penduduk (tenaga kerja) setempat

Dari pertimbangan kualitatif di atas, spesifikasi mesin dan peralatan yang dipilih haruslah yang mendukung teknologi pembuatan produk kaldu instan. Untuk memilih mesin dan peralatan ini, saran dan pertimbangan dari pihak ahli juga diperlukan dan disertai perhitungan kasar seperti kemampuan pendanaan, biaya produksi dan kondisi-kondisi lainnya.

Penentuan mesin dan peralatan ditentukan dengan cermat sesuai dengan penggunaannya agar mempunyai kapasitas produksi berimbang dan demi tercapainya efisiensi arus produksi. Efisiensi mesin dan tenaga kerja sangat penting dilakukan untuk menghindari adanya penimbunan bahan-bahan produksi dalam proses produksi.

\subsubsection{Utilitas}

Utilitas adalah bagian yang sangat penting untuk kelancaran proses produksi suatu pabrik karena utilitas merupakan penunjang beroperasinya mesin atau peralatan yang digunakan dalam proses pembuatan bahan baku menjadi produk dalam suatu pabrik. Utilitas yang digunakan dalam proses pengolahan produk kaldu instan adalah air, listrik dan bensin.

a. Air

Air dibutuhkan sebagai air proses pencucian bahan-bahan baku, air sanitasi, dan air minum. Kebutuhan air per hari untuk unit pengolahan produk kaldu instan adalah 3,2 Liter. Sumber air diperoleh dari PDAM

b. Listrik

Sumber listrik utama bagi unit pengolahan produk kaldu instan berasal dari PLN. Listrik dibutuhkan untuk penerangan, proses produksi (sumber tenaga untuk menggerakkan mesin produksi) dan peralatanperalatan lain seperti komputer dan printer. Kebutuhan listrik per hari adalah 33,85 Kwh.

c. Bensin

Bensin digunakan untuk bahan bakar alat transportasi yang digunakan. Kebutuhan bensin per hari adalah 15 liter.

\subsubsection{Tenaga Kerja}

Tenaga kerja untuk unit pengolahan produk kaldu instan ini direncanakan sebanyak 7 orang yang terdiri dari 2 tenaga kerja tidak langsung yaitu, pimpinan, tenaga administrasi dan sopir serta 5 orang tenaga kerja langsung. Untuk tenaga kerja langsung terdiri atas 2 orang tenaga kerja proses produksi serta 2 orang tenaga kerja pemasaran. Pada 
proses pengolahan dibutuhkan tenaga kerja yang terampil dan cekatan. Diharapkan dengan tenaga kerja yang terampil dan berpengalaman maka proses pengolahan produksi kaldu instan dapat berlangsung dengan cepat. Tenaga kerja direkrut dari daerah sekitar berdirinya unit pengolahan produk kaldu instan, sehingga diharapkan dapat membuka lapangan kerja bagi masyarakat sekitar.

Tenaga kerja merupakan bagian dari keseluruhan proses produksi yang menjalankan setiap tahapan produksi. Untuk menunjang proses produksi kaldu instan sebenarnya tidak dibutuhkan banyak tenaga kerja langsung karena proses produksinya cukup sederhana. Tenaga kerja sebagian besar diperlukan untuk menangani proses pengolahan, selain itu diperlukan juga tenaga kerja yang menangani pengemasan.

Tenaga kerja yang bertugas untuk mengawasi jalannya mesin produksi sebelumnya telah diberi pengarahan dan pelatihan. Penguasaan teknologi pengolahan produk kaldu instan tidak rumit, sehingga pelatihan yang diberikan diharapkan mampu menjalankan operasi produksi dengan baik. Begitu juga dengan tenaga kerja pada bagian pengemasan.

\subsubsection{Analisis Finansial}

Analisis finansial dilakukan untuk mengetahui tingkat kelayakan unit pengolahan pembuatan produk kaldu instan. Analisis finansial meliputi analisis kebutuhan modal, biaya operasional, analisis Break Event Point (BEP), dan analisis kelayakan investasi yang meliputi perhitungan Payback Periode, Net Present Value, dan Profitability Index. Analisis finansial pendirian unit pengolahan produk kaldu instan dilakukan dengan menggunakan asumsi-asumsi sebagai berikut:

- Kapasitas produksi tetap selama umur ekonomis proyek yaitu 5 tahun.

- Perusahaan didirikan di Kecamatan Kromengan Kabupaten Malang.

- Harga dan biaya perhitungan kelayakan finansial adalah yang berlaku pada saat perhitungan (minggu kedua bulan Agustus 2008)

- Bahan baku tersedia sepanjang tahun

- Harga bahan baku, bahan pembantu, bahan pengemas, utilitas, dan gaji tenaga kerja langsung maupun tidak langsung mengalami kenaikan secara proporsional setiap tahun berdasarkan tingkat inflasi yang berlaku, sesuai dengan perkiraan laju inflasi oleh Bank Indonesia yaitu untuk tahun 2008 sebesar $15,40 \%$.

- Nilai suku bunga deposito sebesar $11 \%$ berdasarkan suku bunga deposito yang dikeluarkan oleh Bank Mandiri.

- Pajak penghasilan dihitung 
berdasarkan Undang-Undang

Perpajakan Pasal 17 No. 17 tahun

2000 yaitu penghasilan antara 0-25

juta dikenakan pajak 5\%, penghasilan antara 25-50 juta

dikenakan pajak $10 \%$,

penghasilan antara 50-100 juta

dikenakan pajak 15\%, dan

penghasilan di atas 100 juta

dikenakan pajak $30 \%$.

\subsubsection{Kebutuhan Modal}

Kebutuhan modal meliputi investasi tetap dan modal kerja. Kebutuhan dana untuk investasi tetap meliputi biaya persiapan dan perijinan, mesin dan peralatan, kendaraan, peralatan kantor dan biaya tidak terduga sebesar 10\% untuk menutup kebutuhan dana yang tidak terduga sebelumnya. Modal tetap yang dikeluarkan sebesar Rp. 168.311.000.

Modal kerja adalah pengeluaran untuk membiayai keperluan operasi dan produksi pada waktu proyek pertama kali dijalankan. Kebutuhan dana untuk modal kerja terdiri dari gaji staf administrasi dan penjualan, upah tenaga kerja langsung, sopir, biaya bahan baku dan bahan pembantu, biaya bahan pengemas, biaya utilitas, biaya pemetiharaan alat dan bangunan, biaya administrasi dan biaya telepon. Modal kerja dalam rencana pendirian industri kecil produk kaldu instan ini dihitung untuk jangka waktu 3 bulan operasi sebesar Rp. 116.726.831,25. Dengan demikian total modal yang diperlukan sebesar Rp. 285.037.831,25. Kebutuhan modal ini dibiayai seluruhnya dengan modal sendiri tanpa meminjam dari pihak lain.

\subsubsection{Biaya Operasional}

Biaya operasional yang dianalisis meliputi biaya tetap dan biaya tidak tetap atau variabel tahunan. Biaya tetap adalah biaya yang besarnya tetap dan tidak tergantung pada volume produksi. Biaya tetap yang dikeluarkan terdiri dari gaji staf administrasi dan penjualan, biaya pemeliharaan alat dan bangunan, depresiasi, reinvestasi mesin dan peralatan yang lebih kecil dari umur proyek, biaya beban utilitas, pajak bumi dan bangunan, biaya administrasi, dan biaya transportasi. Pada perencanaan ini, biaya tetap dihitung setiap tahun karena memperhitungkan inflasi dan pengeluaran untuk membeli alat yang memiliki umur lebih pendek daripada umur ekonomis proyek pada tahun-tahun tertentu. Biaya tetap yang dikeluarkan selama satu tahun pertama Rp. 179.517.567. Biaya tidak tetap atau variabel adalah biaya yang bervariasi langsung secara proporsional dengan perubahan volume produksi. Biaya ini meliputi upah tenaga kerja operasional dan sopir, biaya bahan baku, dan bahan pembantu, bahan pengemas, dan biaya utilitas. Besarnya biaya variabel pada tahun pertama adalah Rp. 421.140.525.

\subsubsection{Penetapan Harga Jual dan} Analisis Break Even Point (BEP)

Produk kaldu instan ini 
dijual dengan harga Rp. 224,39/5 g. Harga Pokok Penjualan produk kaldu instan ini adalah Rp. 149,6/5 g.

Hasil analisa Break Even Point (BEP) menunjukkan bahwa kapasitas produksi yang ditetapkan dapat memberikan keuntungan bagi perusahaan. Dengan kapasitas produksi penuh sebesar 1.502.144,47 unit, maka nilai dari BEP sebesar Rp. 337.072.335,84.

4.4.10. Analisis Kelayakan Investasi

Pada perencanaan ini, perhitungan untuk menentukan layak tidaknya proyek investasi dilihat dari hasil perhitungan Payback Periode (PP), Net Present Value (NPV), dan Profitability Index (P1). Proyeksi rugi laba selama periode tersebut diperoleh Payback Periods yaitu : 2 tahun 4 bulan 16 hari. Hasil perhitungan ini bahwa Payback Periods lebih pendek daripada umur ekonomis proyek (5 tahun), sehingga usulan investasi ini layak untuk dilakukan. Hasil perhitungan Net Present Value (NPV) memberikan nilai sebesar Rp. 260.146.456,06. Nilai ini menunjukkan selisih nilai sekarang dari manfaat dan biaya setiap tahunnya. Nilai NPV yang lebih besar dari nol ini juga memberikan arti bahwa unit pengolahan ini layak untuk direalisasikan. Nilai PI hasil perhitungan adalah sebesar 1,91. Nilai PI yang lebih besar dari satu menunjukkan bahwa unit pengolahan ini layak untuk direalisasikan. Pada analisis ini, dapat dilihat bahwa usaha ini mampu memberikan keuntungan bagi perusahan setiap tahunnya. Perhitungan aliran kas proyek tiap tahunnya dilakukan sebagai dasar untuk menilai kelayakan investasi tersebut. 


\section{Diagram Alir Pembuatan Kaldu Ayam Dan Brokoli Instan}

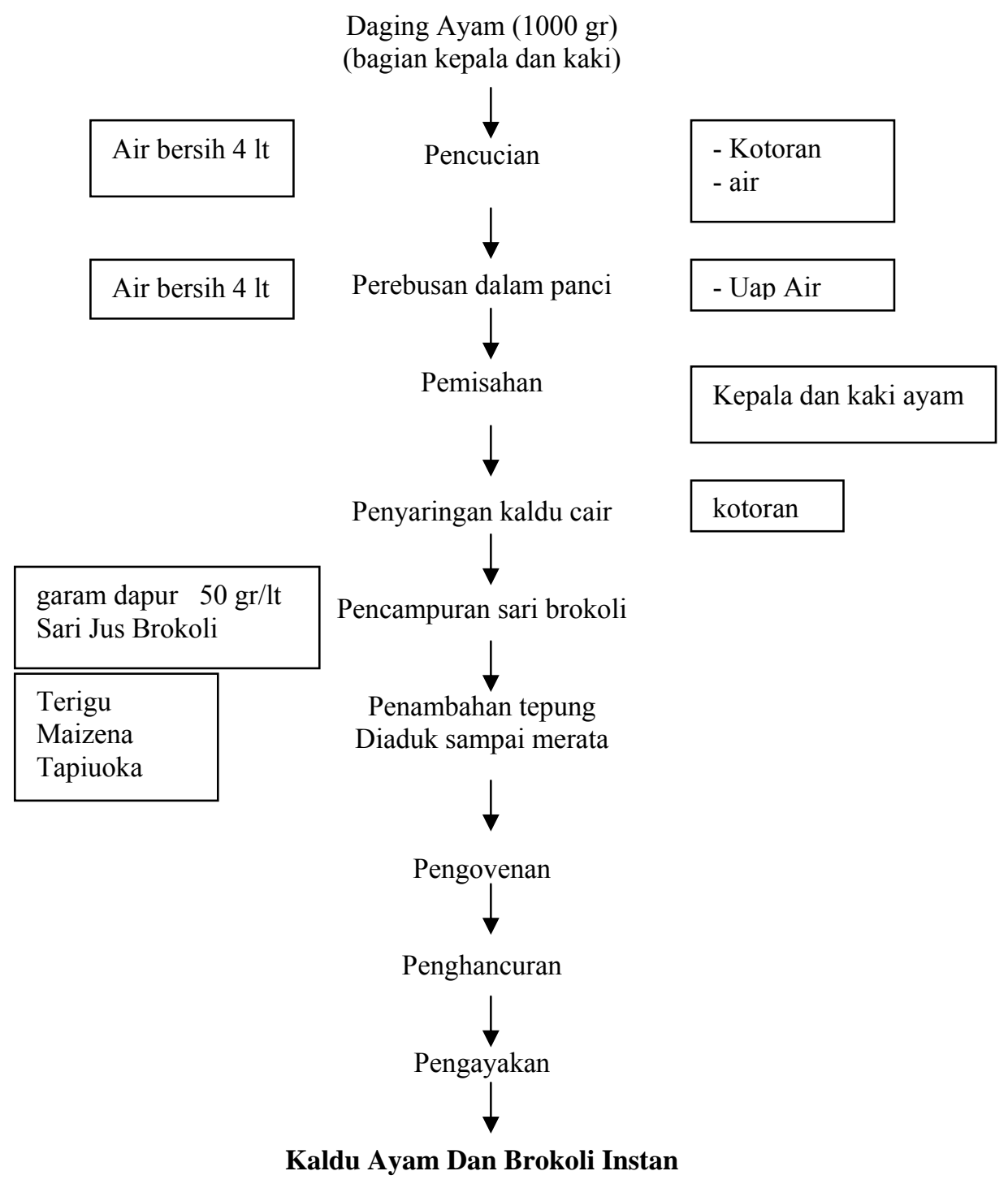

Gambar 13. Diagram Alir Pembuatan Kaldu Ayam Dan Brokoli Instan 


\section{KESIMPULAN DAN SARAN}

\subsection{Kesimpulan}

Dari hasil penelitian disimpulkan bahwa :

a. Perlakuan terigu dengan berat 100 gram merupakan perlakuan terbaik yang menghasilkan produk kaldu ayam instan dengan memiliki karakteristik sebagai berikut: kadar air $5,93 \%$; kadar protein $11,22 \%$; kadar lemak 7,24\% dan warna kekuningan $\left(b^{*}\right)$ 2,31.

b. Perlakuan dengan penambahan proporsi brokoli $250 \mathrm{~g}$, merupakan perlakuan terbaik yang memiliki karakteristik sebagai berikut: kadar air 5,93\%; kadar antioksidan $42,70 \%$; kadar protein $16,60 \%$, kadar lemak $5,43 \%$ , kadar serat kasar 2,15\%, rasa 3,45 , warna 4,9 dan aroma 3,2 .

\subsection{Saran}

Perlu dikaji pengaruh produk kaldu ayam dalam bentuk instan menggunakan jenis pengental lain serta proporsi berat brokoli yang lebih tinggi sehingga hasilnya lebih optimal baik secara teknis dan finansial. 


\section{DAFTAR PUSTAKA}

Anonymous. 2000. Tepung Tapioka. http://www.warintek.net/tepungtapioka Tanggal akses 15 Januari 2007.

2003 ${ }^{\mathrm{a}}$. Kaldu dan Konsome. Infostandar BSN no 1. hal. 4.

2003 ${ }^{\mathrm{b}}$. Masyarakat Mencari Makanan Serba Praktis. http: ||www.kompas.com. tanggal akses 15 Januari 2007

2004. 20 Cara Hidup Sehat Dan Panjang Umur. http://www.RRI.com. Tanggal Akses 7 Agustus 2004

, 2005. Yang Penting Kaldunya. http:indosingmum.blogspot.htm. Tanggal akses 15 Januari 2007

, 2005'. Tanya Jawab Seputar Nutria, Makalah Lifestyle, edisi 5502 IND ID V7.05

$2005^{\mathrm{b}}$. Agar Tak Salah Memilih Bakso. http: \www.republika.co.id. tanggal akses 16 mei 2007

, 2006 ${ }^{\mathrm{a}}$. Penerapan Higiene Dan Sanitasi Pada Industri Pangan (IPSS). BPPOM, Jakarta.

$2007^{\mathrm{a}}$. Membuat Sendiri Aneka Jenis Kaldu. http: \home.blog.htm. tanggal akses 3 November 2007

2007 . Semangkuk Kaldu Hangat. http://www.Feminaonline.com. tanggal akses 15 Januari 2007.

$2007^{\mathrm{d}}$. Sejuta Peluang di Bisnis Makanan.
http://panganplus.com/news.php?bid=19 Tanggal akses 29 Mei 2007

, 2007 .10 Foods You Can't Live Without!. http://www.health forum.com. Tanggal Akses 29 April 2007.

2008 . Tepung, http://id.wikipedia.org.tanggal.htm . Tanggal Akses 18 Maret 2008.

2008 . Macam-Macam Tepung. http://kamusdapurku. Blogspot.com. tanggal akses 6 Agustus 2008.

, 2008 . Brokoli. http://id.wikipedia.org.tanggal.htm. Tanggal Akses 6 Agustus 2008

Apriadji, Wied Harry. 2001. Menimbang Keunggulan Sayuran Daun. http://www.sayur.htm tanggal akses 15 Januari 2007

Annaselby dan Dona van den Berg. 2004. Makanan Berkhasiat: 25 Makanan Bergizi Super untuk Kesehatan Prima. Erlangga. Jakarta.

Buckle, K. A., R. A. Edward., G. H. Fleet., M. Wootton., 1985. Ilmu Pangan. diterjemahkan oleh Hari Purnomo dan Adiono. UI Press. Jakarta.

Cahyadi, Wisnu. 2006. Bahan Tambahan Makanan, Analisis dan Aspek kesehatan. Bumi Aksara. Jakarta. 